\title{
ÇIN TIYATROSU
}

\author{
TARIHSEL GELIŞMESİ VE ÖZELLİGì
}

\section{Prof. Dr. MUHADDERE N. ÖZERDİM}

Çin halkı tiyatroya çok düşkündür. Daha aile ocağında iken tarihsel olaylar, mitoloji kahramanları onlara dedeleri ve masalcılar tarafından anlatılmış ve değerlendirilmiştir. Bütün bunlar çin tiyatrosunda epik, dramatik ve lirik sanat türleri içinde onların gözleri önüne serilir ve canlandirilir.

Geleneğe bağlı olan Çin tiyatrosu, müzik, dans, konuşma, pandomim ve akrobasi üzerine kurulmuştur. Burada müzik en önemli rolü oynar $^{1}$. Dramatik bir yapısı olduğu kadar müzikal bir yapısı da vardır.

1 Çin'de müziğin çok eski çağlarda varolduğunu görüyoruz. Fakat bu müziğin bir eğlence aracı olmaktan ziyade dinsel maksatlarla yapıldığını anlıyoruz. Shang sülalesi zamanında (M. Ö. 1600-1028 (yeni kronolojiye göre. Bak. W. Eberhard: A history of Chiana Berkeley, 1969.s.19) fal kemiklerinde 'müzik' kelimesine ve sonra 6 çeşit müzik aletine (davul, gonk, ses taşları, flüt ve tüy ve kamıştan yapılmış kaval) rastlıyoruz (bak. Shıh Chi: 24. Müzik bh. I. s. 2a, 5 b, ve 6 b). Chou sülalesi zamanında (M. Ö. 1028-257) müzik zengindi. sarkılar için birçok ses tonunun adları verilmektedir. Sonra Konfüçyüs'ün đüzenlediği Shıh Ching'de (Şarkılar kitabı) 305 kadar, halk türkülerini, dinsel ve dinle ilgili olmayan tören şarkılarını bulabiliriz. Bu çağlarda müziğin kutsal insanlar tarafından tanrıları (Gögü) memnun etmek, halka neşe vermek, bununla onları yönetmek ve nihayet erdemi yaymak için yapıldığı kaydedilir. (Bak. Shıh Chi: 24. Müzik bn. s. 7-8 b, 9 a, 10 b. Ve Chien Han Shu: 22. Müzik bh. $7-8$ b). Yine bu belgelerden Atalar tapınağında kurban törenlerinde müziğin eşliğinde bir takım danslar yapıldığını öğreniyoruz (Bak. Chien Han Shu: 22. Müzik bh. s. $9 \mathrm{a}-12$ b).

Atalar tapınağında kurban törenlerinde müziğin eşliğinde bir takım danslar yapıldığını ögreniyoruz (Bak. Chien Han Shu: 22. Müzik bh. s. 9a-12 b).

Bundan başka, bu çağlarda müzik Çin toplumunun eğitiminde ve sonra devletin yönetiminde esaslı bir prensip olarak kabül ediliyordu. Onlara göre, 'kötü müzik halkı, örf ve adetleri ve kanunları bozar, devleti sarsar. Bunun için bu tür müzik yasak edilmelidir (Bak. Yueh Chi (Müzik hakkında notlar) Böl. I - II.).

Chou sülâlesinden sonraki sülâlelere ait tarihsel belgelerde Çin müziğine ait bölümler buluyoruz. Burada müzik dinsel törenlerden başka ziyafetlerde, toplantılarda bir ę̆- 
Kısaca bir opera türüdür diyebiliriz. Burada aktörün üstünlüğü, önce şarkı söyleme sanatında ve sonra sesinin ahenk ve tatllığında aranır. Bunların yanında ses tonunun oyundaki rolüne uygun olması beklenir. Zira her rolün kendine has bir vokal tekniği vardır. Şarkılar, konuşmalar, aksiyon ve ritimler bu tekniğe uygun olmalıdır. Bu şekilde bir çinli seyirci, sahneden artistçe bir oyun beklediği gibi, en yüksek imkân dahilinde de şarkıda, konuşmalarda incelik ve güzellik bekler. Bu da yine gerçek bir sanat anlayıcısını kendinden geçirebilir. Çünkü Çin sahne sanatını sathi bir görüşle değerlendirmek isteyenler, bunlaın bir sanat olarak kabul etmek istemezler. Şu da bir gerçektir ki, Çin ruhuna nufuz edebilmek, tiyatroda hakim olan sembolizmi kavrayabilmek güçtür. Zira, uzun zamandanberi gelenekçi ve ve buna bağlı, bunun etkisiyle yan yana yürüyen teknik ve şekil Çin sahne sanatına serbest bir ilerleyiş ve görünüș alanı bırakmamıştır. Yalnız gelenek üzerinde yürüyen böyle canlı bir kültürün anlatılması pek güçtür. Bunları kavrayabilmek için, insanda kuvvetli bir muahyyile ve oyundan anlayış yeteneğinin bulunması gerekir. Böyle bir kabiliyeti kendimizde bulduğumuz zaman, Çinlilerin aktörün kişiliğinde yaratmış olduğu tarihsel kahramanı alkışlarken gösterdikleri takdir mırıltılarını duyar ve göğüslerinin kabardığını ve gözlerindeki seviç kıvılcımlarını görmüş oluruz. O zaman zevki en incelmiş olanlar bile şekli unutup yalnız özü anlamış olacaklardır.

Böylece biz, Çin tiyatrosuna sahne olan imparator ve imparatoriçelerin saray maceralarını, asillerin kanlı döğüşlerini, bilginlerin ve ve filozofların yaşantılarını gösteren oyunları zihnimizde yaşatır ve gözümüzün önüne serersek, hiç şüphe yoktur ki, Çin tiyatrosunun cehenneme benzer hali bizi şaşkınlığa ve hayrete düşürmez ve o zaman onun değerini anlamıs oluruz.

\section{Çin Tiyatrosunun tarihsel gelişmesi:}

Çin tiyatrosunun başlangıç tarihinin çok eski çağlara kadar gittiği kabul edilir.

Hsia sülâlesi (M. Ö. 2000-1600) imparatorlarından Chieh-kuei'yin (M. Ö. 1763) gözdesi 'Mo-hsi'yi eğlendirmek için saraya pek çok oyun-

lence aracı idi. Her imparator bu müziğe önem vermiş ve biraz da gelişmesine yardımc1 olmuştur (Bak. Sui Shu: 13. Müzik bh. s. 2 a - 3 ab, 7 a, a 19 b. 30-33 a b. Sui Shu: 14. s. 30-31 - 32 a b. Ve Sui Shu: 15 . Müzik bh. s. 1 a b, 28 a b. VE. Chiu T'ang Shu: 28-31. Müzik bh. s. 1-2-10 a b. Ve Sung Shıh: 126-142 Müzik bh. ). işte Bu eski müzik, zamanla Batıdan gelen müzikle karışarak özelliğini kaybetmiş ve birçok müzik uslupları meydana gelmiştir ki, bunlar gerek K'un C'hü ve gerekse Ching Hsi tiyatrolarının müziği olmuştur. 
cu davet ettiği ve dram yazarlarını toplayarak piyesler yazmaları için emirler verdiği hikâye edilmektedir ${ }^{2}$. Hsia sülâlesine ait yazılı belge bulunmadığı göz önünde tutulursa, bunun doğru olmıyacağını ve sadece bir hikâyeden ibaret kalacağını kabul edeceğiz.

Chou hanedanının egemenliği sırasında feodal beğlerin gerek özel ve gerekse genel eğlencelerinde 'Wu' denilen dansörler tarafından şarkı ve danslar yapıldığı, hatta Lu Dükü'Yin'in (M. Ö. 176) 5. inci saltanat yılında tamamlanan Chun-tzu sarayının tapınağında, ilk defa müziğin eşliğinde bir takım danslı ve şarkılı temsiller verildiğinden bahsedilir ${ }^{3}$. Bu oyunlardaki aktörleri devlet hizmetinde kullandıkları da kaydedilir ${ }^{4}$.

Yine Chou imparatorlarından Hsiang Wang'n saltanatının 28'inci yılında (M. Ö. 623) Ch'en ve Pao adlı iki kürek mahkumunu getirterek sarayınnda oyunlar yaptırdığı ve kralın kardeşi Meng Ch'ang'ın bundan hoşlanmadığı Tso Chuan'da kaydedilmiştir 5 .

Kuo Yü'den (devlet hak. konuşmalar) alınan bir kayde göre, 'Konfüçyüs Lu Derebeğliğinde Adalet Bakanı iken, Ch'i derebeğinin onun şerefine verdiği bir ziyafette saray cücelerinin ve hokkabazlarının

2- Bak. L. C. Arlington. The Chinese drama. Shanghai. 1930. s. 9.

3- Chou sülalesi zamanında bu danslardan bașka ve Shen-hsi denilen 'Kutsal oyunlar'in yanında, 'Sung Wu' denilen 'methiye dansları' vardı. Bu danslar da yine Tanrıların ve Atalarının ruhlarına bir nevi sunaktı. Ve aynı zamanda üstün erdemin bir gösterisi idi. Bu dansların müzik aletleri, gonk, davul, flüt, ses taşları ve tüyler idi (bak. Shıh Ching (Chung bölümü ve Chou sung bahsi). Ve, shih chi: 24. s. 6 b.

- Chien Han Shu 22. s. 8 b, 9 a. s. $4-5$.

- Chung-kuo Hsi-chi Shıh (Çin tiyatro tarihi. Yazan: Tang-Sui- nien. Taipei 1956.

- Chung-kuo Chin Hsi-chü Shıh (Yakın zamanlar Çin tiyatro tarihi (yazan: Ching Mu-cheng-erh (Japon). çev. Wang Chi-hu), Taipei, 1965. C. I. s. 2-3.

- Hsi-ch'ü Tsung-t'an (Tiyatro hakkında konuşmalar. Yazan: Hua-lien-p'u). Taıpei 1967. s. 1-2.

- J. Legge: The Chinese Classics C. V. The Ch'un Ts'ew with Tso Chuan. Hong Kong. 1960. s. 18-19.

- Heinz Kindermann: Fernostliches Theater. Stutgart. 1966. s. 262.

4- Bu zamanda devlet hizmetinde görevi olan aktörlerden en ünlüsü Yu Men'dir (Bak. Shıh Chi: 126 "Hua Chi- Şakalar bahsi”. s. 1 a -5 b.).

- Chung-kuo Hsi-chi Shıh. s. 6.

- Chung-kuo Chin-shıh Hsi-chü Shıh: c. I. s. 2-3.

- H́si-ch'ü Tsung-t'an: s. 2.

5- Bak Arlington: Aynı eser. s. 10.

- Bu olay için (Hsiang Kung'un 28'inci saltanat yili) bak: Ch'un Ch'iu Tso Chuan. s. 287 (13 kitap-Sh1-san Ching. 1914, Shanghai, Commercial press).

- J. Leğğe. Ayni kitap. s. s. 536-543. 
birtakım oyunlar yaptığını görmüş, bunları ahlâka uygun bulmayarak bu oyunları yapanları öldürtmüştür ${ }^{6}$.

Shıh Chi'de ise bu olaya dair şöyle bir kayıt vardır: "Konfüçyüs Lu Derebeğliğine Adalet Bakanı olunca komşu derebeğliği Ch'i onun nufuzundan korkmuş. Bunu önlemek için Lu Derebeğliğine müzisyenler ve kadın oyuncular göndermiştir. Lu Derebeğinin yavaş yavaş eğlenceye daldığını ve doğru yoldan ayrıldığını gören Konfüçyüz Bakanlıktan istifa etmiştir?.

Konfüçyüs'ün öğrencileriyle yaptığı konuşmaları içinde toplayan Lun-yü de (Konuşmalar kitabı) bu konu ile ilgili bir pasaj vardır. 'Ch'i halkı Lu Derebeyliğine kadın ve müzisyenler (Güzel kadınlar ve atlar) gönderdi. Chi Huan (Chi ailesinin Başkanı) bunları kabul etti ve saray üç gün kapalı kaldı. Konfüçyüz burasını terkedip gitti ${ }^{8}$.

Ch'in imparatoru Shih Huang-ti'nin (m. ö. 210-246) A Fang sarayında en aşağ 130.000 kadar aktörü olduğu ve bazılarını saray müşaviri yaptığı ve sonra bunlardan başka sarayda danseden ve şarkı söyleyen güzel kızların bulunduğu ileri sürlür'.

6- Arlington. s. 7.

- Kou-yü'nin, Lu Derebeyliği (Böl. IV-V s. 36-52) ve Ch’i Derebeyliği (Böl. VI, s. 52-59) bahislerinde böyle bi kayde ratslamiyoruz. Bu olaydan Chia-yü bahsetmektedir (bak. Hou Han Shu. 81. Li Hsün bahsi. 4. s. 2. b).

7- Bak. Shıh Chi: 47. s. 10 a b (Konfüçyüs'ün biyografisi).

8- Konfüçyüs'ün Adalet Bakanı olduğuna dair 'Meng-Tzu (2, 209)' ve Tso Chuan'da (M. Ö. 503-501) bazı kayıtlara rastliyoruz. Fakat yapılan incelemeler sonunda bunun doğru olmadığı görülür. Meng-tzu'tzu'nın bu mushası daha sonraki bir baskıdır. Burada Konfüçyüs'ün niçin görevinden ayrılıdığını söylemez. Tso Chuan ise Konfüçyüs'ün görevinden ayrılma nedeninden hiç bahsetmez. Lun-yü'de ise O'nun Adalet Bakanı veyahut buna benzer yüksek mevkilerde hiçbir şekilde yer almadığını kendi ağzından öğreniyoruz (bak. Lun-yü: Böl. II, 21 IX. 6) ve

- Türkçe çevirisi : Muhaddere N. Özerdim. Konuşmalar 'Konfüçyüs'. Milli Eğitim Bakanlığı yayınlarından. Ankara. 1963. Böl. XVIII. s. 132. ve Böl. IV. not. 124.

9- Shıh huang-tı'nın sarayında koruduğu ve devlet işlerinde görev verdiği en ünlü artıstlerden biri Yu Chan'dı. Bu aynı zamanda cücedir (Shıh Chi: Bh. 126. s. 5 b-6 a ) $\mathrm{Ve}$,

- Chung-kuo Hsi-chi Shıh: s. 5-6. Ve,

- Chung-kuo Chin Shıh Hsi-chü Shih. C. I. s. 3.

- Hsi-ch'ü Tsung-t'an. s. 2,

- Arlington: s. 10

- Ch'in umparatoru Shıh huang-ti, Chou'ların danslı şarkılarından çok faydalanmıştır. 'Ta Wu'yu alıp değiştirmiş 'Wu Wsing Wu demiştir (Bak Sui Shu: 15, Müzik bh. II. s. la, ve Chung-kuo Hsi -chi Shıh. s. 5). 
Han sülalesi imparatorlarından Kao-tsu (M. Ö. 206-194) zamanında tarihsel bir olayın Çin tiyatrosunun başlangıcı olduğunu ileri sürerler. $^{10}$

"Çin ordusu Hsiung-nu'lar (Hun'lar) tarafindan Shansi'de P'ing Ch'eng mevkiinde kuşatılyyor. Hun Hakanı Mao-tun (Mete) şehrin her tarafını kuşatırken iç kalenin dördüncü duvarının sarılmasını karısına (Yen-chi) veriyor. Erzak tükenip açlık baş gösterince, Çin orduları komutanı bu kuşatmayı kaldırmak için bir hile buluyor. Maotun'unun karısının çok kıskanç olduğunu biliyordu. Kuşatılan duvarın önüne çok güzel yapılmış kadın kuklaları koyduruyor. Ve bunlara canlı süsü verdirmeğe çalışıyor.

Mao-tun'un karısı bu kuklaların birtakım çekici danslar yaptığını görünce, şehirde güzel kadınların bulunduğuna kanaat getirerek kuşatmayı hemen kaldırıyor ve ordularını geri çekiyor. Bu suretle Çinliler açlik ve kuşatmadan kurtuluyorlar."

Bu tarihsel olayın Çin dramının başlangıcı olup olmadığı üzerinde kat'i bir fikir ileri sürülemez. Anak kuklaların meydana gelmesini sağlamıștır diyebiliriz.

Üç imparatorluk çağında (M. S. 220-280) Wei sülalesi imparatorlarından Ming-ti tiyatroya çok düşkündü. 'Bronz Saksağan' adlı sarayında birçok aktörleri toplamış ve temsiller verdirmiştir. Bu zamanda şarkı ve danaslar vardı. Ming-ti bunları çok seviyordu. İmparatorun bu şarkı ve dansları geliştirdiği kaydedilir ${ }^{11}$.

Sui sülalesi (580-618) imapatoru Yang-ti de zamanının önemli bir kısmını tiyatroya vermişti. Bu düşkünlüğünden dolayı 'Sevinç Sarayını' (Li-kung) yaptırmış ve burada yüzlerce aktörü barındırmış ve kendi yönetiminde birçok temsiller verdirmiştir ${ }^{12}$.

10- Chien Han Shu: (Kao-tsu bh. Böl. 2. s. 11 b).

- Han imparatoru Wu-ti de, iyi bir devlet adamı ve askerdi. Fakat dans ve şarkılardan da çok hoşlanırdı. Her eyaletten şarkılar toplattı ve Müzik okulu'nu (Yuch Fu'yu) kurdu (Bk. Chien Han Shu: 22. s. 13. ve Chung-kuo Hsi-chi Shıh: s. 8).

11- Arlington. s. 11.

- Sui Shu: 13. Müzik bahsi. II. s. 2 b. 19 b.

- Sui Shu: 15. Müzik Bahsi. II. s. 1 b.

12- Arlington. s. 11.

- Sui Shu: 15 müzik bh. II. s. 30 b, 32 b.

- Hsi-ch'ü Tsung-t'an. s. 5.

- Chung - kuo Hsi-chi Shih. s. 16-18. 
T’ang sülalesi (618-906) tiyatro için bir rönesans çağı olmuştur diyebiliriz. Zira tiyatro yukarıda görüldüğgu gibi daha önceleri, bir meslek olarak bir varlık kazanamamıştı. Bu oyunların bir kısmı 'Shen-hsi' denilen 'kutsal oyunlar'd1, ve dinsel bir nitelik taşıyordu. Gayesi erdemi anlatmak ve yaymaktı. Bunlar sihirbazlar $(\mathrm{Wu})$ ve büyücüler tarafindan yapilıyordu. Bunların yanında dinsel olmayan, toplantılarda, bayramlarda bir eğlence aracı olarak yapılan danslı ve şarkılı oyunlar da vardı. Ayrica geleneğe göre aile ve klana mensup 'Ata'ların şerefine yapılan ve âyinlerle ilgili kutlama törenleri de vardı. Bunlara orta oyunları, karagözleri, kuklaları ve akrobatik oyunları da katabiliriz. Bunların içinde eski bir dramatik şekil olarak kabul edilen şarkı ve diyaloğlar da vardı. Fakat gerçek bir dram için bir başlangıç sayılamazdı. Bu bakımdan, T'ang imaparatorlarından Ming Huang (M. S. 712-750) Tiyatronun eskisine nazaran her bakımdan gelişmesine yardımcı olmuştur diyebiliriz. O müzik ve şarkıyla meşgul olan genç ve güzel kızlar için, 'Li-yüan Chiao-fan'dan (Armut bahçesi Akademisi) başka, I-ch'un Yüan'ı (ölmez ilkbahar bahçesi) kurmuş ve tiyatro sanatı ile ciddi şekilde uğraşmıştır. Kabiliytli herkesi himayesine almış ve saraydaki temsiller için yetiştirmiştir. İmparator da bizzat bu temlere katılmıştır. Fakat bilginler, bilhassa Konfüçyanistler sarayın tiyatro ile ilgisini hoş görmemişler ve aktörleri toplum dışi saymışlardır. ${ }^{13}$

Sung sülâlesi zamanında (960-1279) imaparator T'ai-tsung ve Cheng-tsung da tiyatroya çok önem vermişlerdir. Hua-lin -hsi (çeşitli ormanlar) ve 'Ts'ui-chin-she (süslü elbiseler toplumu)' gibi tiyatrolar kurmuşlardır. Burada temsil edilen oyunlar danslı ve şarkılı idi. Ve daha-ziyade halkın duygularını yansitıyordu ki, saray halkı bundan hoşlanmamışır. ${ }^{14}$

13 Chiu T'ang Shu. 28. Müzik Bh. I. s. 28 b.

- Chung-kuo Hsi-chi Shıh. s. 19-21.

- Chung-kuo Chin-shıh Hsi-ch'ü Shıh. s. 5

- Hsi - ch'ü Tsung-t'an. s. 6-8.

- T’ang sülalesine ait kral mezarlarında aktör ve dansörleri temsil eden imajlar vardır. Bunların yabancı tipler olduğu ve daha ziyade asiatik modellerden ilham alınarak yapıldı̆̆ı göze çarpar (Arlington. s. 4).

- Prof. Eberhard, Çin tiyatrosunun iki kaynaktan geliştiği kanaatindedir.: 1- Kuzey kavimlerinden gelen (Türk ve Moğolların kült oyunları) danslı temsiller. Bilhassa kılı̧̣ oyunları. Bunlar sonradan askeri piyesleri meydana getirmiştir ki, burada esas olan şey danstır. Müzik sonradan gelir. 2- Güney Çin asıllı kurban törenlerindeki oyunlar. Bunlar da sivil piyesleri (romantik olan dramlar) meydana getirmiştir (W. Eberhard: Çin Tarihi. 1947. Ankara. s. 221. ve A History of China. Berkeley. 1969. s. 182 - 183).

14 Arlington. s. 12.

- Bu şarkılar Sung hanedanının orijinal şarkıları değildir. Kuzey sülalelerinden alın- 
Moğol hanedanının (Yüan sülalesi 1280-1368) gelmesiyle Çin kültürüne birçok yenilikler katılmıtır. Ve zamanla tiyatroda da esaslı gelişmeler görülmüştür. İlk defa olarak tiyatro tekniğine birtakım yeni kaideler konmuştur. Ve tiyatro Kuzey (Pei-ch'ü) ve Güney (Nanch'ü) olmak üzere iki ekole ayrılmıştır. Bu iki ekolün içinde birçok dramatik usluplar da vardır.

Moğol sülalesinin ilk çağlarında doğan bu iki ekolün arasında bazı ayrımlar vardır. Bilhassa oyunların yapılış şekli, müzik, diyalog ve konularında bu ayrımlar göze çarpar. Hepsi ayrı ayrı mahalli ilhamların etkisi altında kalmıştır. Sonra bunlar arasında şarkı ve diyaloglardan ibaret oyunları içine alan Tsa Chü (çeşitli oyunlar) denilen küçük piyesler de vardır. Fakat bunların hiçbiri bu gün mevcut değildir.

Merkezi peking olan ve 1235-1280 yılları arasında en parlak çağını yaşayan 'Kuzey ekolü'nün şarkıları epik bir ruh taşır ve çok canlıdır. Melodileri daha yumuşak ve daha ahenklidir.

'Güney ekolü'nün merkezi Hang-chou idi. Gelişme çağı 12801335 yılları arasındadır. Bu tiyatro uslubunda vezin tekniğine, şiirin uzunluğuna, edebi deyimlere çok önem verilmiştir.' Kuzey ekolü'nde ise kaideler daha serbesttir. Ve her günkü konuşma dilin terimler alınmıştır. ve saray dilinden çok farklıdır. Şarkılarda telli aletler kullanılır.'Güney' piyeslerinde ise telli aletler ikinci derecede kalır. Başlıca müzik aleti flüttür.

Bu iki ekol Ming sülalesine kadar (1368-1644) ayakta durabildi. Bu zamanda 'Güney ekolü' 'Ch'an Ch'i' adiyle daha çok gelişerek toplumun ilgisini çekmeğe başladı. 'Kuzey ekolü' ise etkisini kaybetmeğe yüz tutmuş bir durumda idi.

Ming sülalesinin ilk zamanlarında 'Güney tiyatrosu'nu birkaç ekole ayrıldığını görüyoruz. Bunlar mahalli ihtiyaçlara göre kurulmuș tiyatro toplulukları idi. Menşeilerini muhtelif eyaletlerden almıştı. Burada lehçe önemli bir rol oynar.

Bu sülâlenin orta çağlarında ise dramatist ve bilgin Liang-po-lung ve kompositör, müzisyen olan Wei Liang-fu tiyatroya bir takım yenilik-

mış 'Ta Chü'lerdi. Bunlar 100'den fazla idi. Fakat bir kısmı kaybolmuştur (Bak. Sung Shıh: 126. Müzik h. I. s. 7 a b -8 a b. ve Sung Shıh: 142 : Müzik bh. 17. s. 9 a b -11 a ve 16 b). $\mathrm{Ve}$

- Chung-kuo Hsi-chi. s. 32 (burada 40 Ta Ch'nün adı verilmiştir) ve s. 26, 31, 37.

- Chung-ku Chin-shıh Hsi-ch'ü Shıh s. 6-8 ve 18-26.

- Hsi-ch'ü Tsung-t'an. s. 9-10. 
ler getirdiler. Wei Liang-fu yeni bir müzik uslubunu (Shui-mo-tiao) yarattı ve bu adı taşıyan bir tiyatro ekolünün kurucusu oldu. ${ }^{15}$ Diğer ekoller ise bunun etkisinde kalmağa başladılar. Ve nihayet K'un Ch'ü adını alan yeni bir tiyatro ekolü meydana geldi. ${ }^{16} \mathrm{Bu}$ tiyatronun 300 y1l kadar (1550-1850) Çin sahne hayatına egemen olduğunu görüyoruz.

Böylece, mahalli bir tiyatro olarak $\mathrm{Wu}$ eyaletinde ortaya çıkan K'un Ch'ü Shanghai'ye kadar yayıldı. Uzun yıllar imparatorların, saray halkının, bilginlerin, edebiyatçıların, aktörlerin, hatta tüccarların ve sonra şarkıcı kızların sevgisini kazanmış ve hiçbir zaman değerini kaybetmeyen tiyatro eserleri vermiștir.

Bu zamanda, ipeği, princi bol ticaret ve ekonomisi bakımından zengin olan Soochow bir kültür merkezi idi. En iyi aktörler, şairler ve müzisyenler burada toplanmıştı. K'un Ch'ü burada bir gelişme ve yükselme fırsatı bulmuştu. Sanatçılar, bu tiyatro için en iyi besteler yaptılar ve piyesler yazdılar. ${ }^{17} \mathrm{Bu}$ çağın ilk piyes yazarı ve ünlü bir şair olan Li K'ai-hsin'dir. Ve sonra en büyük dramatistlerden Liang Ch'nen-yü'nün 'Huan-sha nehrinde çamaşır yıkayan kızın aşkı' adlı piyes K'un Ch'ü sahnesine değerli bir eser kazandırmıştır. Bundan sonra, Wuchiang' Ekolünün babası sayılan Shen Ching gelir ki, yalnız piyes yazarı değil, aynı zamanda fonoloji üzerinde de çalışmış bir bilgindir. 17 piyessinancak 3 tanesi kalmıştır. Aynı çağda yaşayan T'ang-hsien-tsu da bir piyes yazarı olarak çok ün kazanmıştır. '4 Rüya' adlı eseri ve 'Eflatun flütün romansı'. onun zengin muahayyilesini ve poetik kabiliyetini gösterir. Kendisini Shakespear ile mukayese ederler. ${ }^{18}$

Mançuların Çin'e eğemen olmasiyle (1644-1911) Peking Başkent yapıldı. Çinin kültür merkezi Kuzeye taşındı. Fakat Soochow henüz henüz kültürel önemini kaybetmemişti. Mançu hanedanının en kuvvet-

15-16 - Bak. Scott: The classical theatre of China. London, 1957. s. 32-33.

- K'un Ch'ü'nün başlangıç tarihinin belli olmadığı ve Wei Liang-fu'nın bir tiyatro kurucusu olmaktan ziyade Ku'n Ch'ü'yü geliştirdiği ve bu tiyatronun daha bir yüz yıl önce varolduğu ileri sürülmektedir (Bak. Yao Hsin-nung. The rise and fall of the K'un Ch'ü. Tien Hsia. Monthly. 1936. Ocak. Shanghai. s. 65).

- K'un Ch'ü, 'Güney şarkı'larına verilen bir ad olarak kabul edilir (Chung-kuo Chin-shıh Hsi-chü Shah. C. I. s. 166).

17 - Bu piyesler 31 kadardır. Ve 5 katagoriye ayrılmıștır (Bak. Chung-ku Hsi-chi: s. 80-84. ve Chung-kus Shch Chin-shıh Hsi-ch'ü Shıh. s. 179-7).

18 - Chung-kuo Hsi-chi. s. 8-87.

- Chung-ku Chin-shih Hsi-chü. s. 202 ve 230. 
li imparatorlarından Kang Hsi (1661-1722) ve Ch'ien Lung (1735-1796) tiyatroya çok ilgi gösterdiler. K'un Ch'ü repertuarını yeniden gözden geçirmek ve eski opera eserlerini toplamak için Yangchou'da bir 'Büro' kuruldu. Ve birçok yeni piyesler yazıldı. Çok değerli sanatçılar ve sanat eserleri bakımından bu imparatorların zamanına 'tiyatronun altın çağı' derler.

Bu çağın en ünlü piyes yazarı Li Yü'dür (1611-1680). Klasik uslupta piyes yazmayı reddetmiş ve yeni dramatik kaideler ortaya koymuş ve sade dilin savunucusu olmuştur. ${ }^{19}$

Hung Sheng ve K'ung Shang-jen bu çağın en ünlü oyun yazarlarındandır. Birçok piyesleri yanında Hung'un 'Uzun ömür sarayı' adlı oyunu T'ang sülâlesi imparatorlarından Ming Huang'ın gözdesi Yang Kuei-fei ile olan aşk öyküsünü anlatır. Çok popüler olmuştur. Kung'un 'şeftali çiçekli yelpaze' adlı oyunu da çok sevilmiştir. Konusu, Ming Hanedanının ünlü yazarlarından Hou Fang-yüeh ile şair ve şantöz Li Hsiang-chü'nün saralarındaki aşk dramıdır. ${ }^{20}$

Saray tiyatrosu diyebileceğimiz K'un Ch'ü, sarayın yardımıle geliştiği ve en yüksek noktasına eriştiği zaman, bunun yanında halkın tuttuğu mahalli tiyatrolar da gittikçe değer kazanıyordu. İmparator Chia Ch'ing (1796-1821) zamanında bu tiyatrolar K'un Ch'ü ile yar1şacak bir dereceye gelmişti.

1850 'de Kuanghsi eyaletinde patlayan T'ai-p'ing isyanı ve sonra Fransızların ve İngilizlerin işgali (1856-1860) Mançu'ların egemenliğini ve ekonomik durumunu sarsmıştı. 1853 'de de Kiangsu eyaletinin isyancıların eline geçmesiyle Soochow'un ekonomik statüsü bozulmuş ve tiyatro sanatçıları dağılmıştı. Bu aynı zamanda K'un Ch'ü'nün de bir daha kendine gelmemek üzere sanat alanından çekilmesine sebep olmuştu. Zaten Mançu hükümeti de sarayın ve yüksek tabakanın lüks içinde yaşamasını ve her türlü eğlencelere gitmesini yasak etmişti. Böylece K'un C'hü her bakımdan himayesiz kalmıştı. Bununla beraber yukarıda bahsi geçen mahalli tiyatroların gruplar halinde yaşadı̆̆ görülüyor.

Bir zaman sonra bu küçük tiyatro grupları birleşerek, Ching Hsi (Başkent Tiyatrosu) adıyle Peking'de yeni bir tiyatronun kurulmasını

19- Bak. Tien Hsia. Aynı makale s. 77.

- Chung Kuo Hsi-chi Shih. s. 97.

- Chung-kuo Chin-shıh Hsi-ch'ü Shıh. s.

20- Chung-kuo Hsi-chi: Shih s. 98.

- Chung - kuo Chin - shıh Hsi - ch'ü Shıh: s. 376-379 ve 383. 
sağladılar. Anhui'li Ch'eng Chang-kêng ve T'an Hsin-p'ei tiyatronun kurucularından sayılır. Bu tiyatro sarayın yardımıyle, bilhassa imparatoriçe Tzu-his himayesinde gelişti ve değerli oyunlar verdi.

Japonya ile savaş (1932-1945) tiyatro faaliyetini durdurmuştu. Japonlar tiyatroyu çok sevdiklerinden, artistleri bu yolda teşvik etmişlerse de sanatçılardan hiç ilgi görmemişlerdir. Ve çinli oyuncular japonlar için oynamak istememişlerdir. İkinci Cihan savaşında ise tiyatro ölü bir çă̆ yaşamıştır diyebiliriz. Milli hükümetin Nanking'de tekrar kurulmasiyle canlanan Ching Hsi, Komünist rejim altında Peking'de ve sonra Honk Kong'da temsiller vermekte devam etmektedir. Ve sonra, Milliyetçi Çinin başkenti olan Taipei'de de klâsik biçimde tiyatronun oyunlar verdiğini görmekteyiz. Bundan başka, Peking Chin Hsi' adında bir çocuk tiyatrosunun kurulmuş olduğunuda öğreniyoruz. $^{21}$

\section{Çin Tiyatrosunun Özelliği:}

Görüldüğü gibi, Çin'de klâsik ve milli diyebileceğimiz tiyatro birçok mahalli tiyatro topluluklarının birleşmesiyle meydana gelmiştir ve uzun yillar Çin toplumunun milli bir eğlencesi olmuştur. K'un Ch'ü ve Ching Hsi denilen bu iki büyük tiyatro ekolünün meydana geşini ve tarihsel gelişmesini kısaca gösterdik. Her iki tiyatronun arasında dramatik sanat bakımından bazı ayrımlar olduğunu burada göreceğiz.

Başlica ayrımı, müzik aletlerinde ve sonra piyeslerin temel yap1lışlarında görülür. Moğol (Yüan) tiyatrosunun bir pro tipi olan 'Kuzey ekolü'nden pek farklı olmayan K'un Ch'ü tiyatrosunda, müzikal terimler ve usluplar çok çeşitlidir. Piyesler daha yumuşak, daha romantik ve daha edebi uslupta yazılmıştır. Burada teknikten ziyade sanata önem verilmiştir. Edebiyatçılar, bilhassa piyes yazmak için yetiştirilmişlerdir. Bu piyesler hem seyirciyi hem de tiyatro meraklılarını düşünerek kaleme alınmıştır.

K'un Ch'ü'de piyesler sahnelere (Chıh) ayrılmıștır. ${ }^{22}$ Burada çeşitli öyküler ve oyuncuların aksiyonları ayrıntılı bir biçimde izle-

21- Bak. Scott: s. 34 .

- Taiwan: Kasım. 1969. s. 21 - 24.

22- Moğol çağının tiyatro piyesleri 4 sahnelikti. Ve her sahnede şarkı söyleyen artisler başka kişilerdi. 4. kişi birarada asla şarkı söylemezdi. 4 esaslı rol veyahut karakter tipleri vardır. Cheng Shen (yaşlı adam), imparator ve general rollerine çıkar. Wu Shen, tipi, ise askeri kahramanları canlandırır. Bunlar birtakım akrobatik oyunlar da yaparlar. Bu bakımdan aktörün iyi bir atlet olması gerekir. Hsıao Sheng (genç adam), her türlü rolleri yapan kişilerdir. 
nir. Her bir sahne aşağı yukarı bağımsız bir oyundur. Dramatik yapılışından başka müzikal bir yapılışı da olan K'un Ch'ü'de müzik çok önemli bir rol oynar. Bu müziğe K'un Ching de denir. Ve Ching Hsi müziğine nazaran daha melodik ve daha yumuşak bir havası vardır. Mahalli dilin özelliği de bu müziğe daha başka bir üstünlük verir. $\mathrm{Bu}$ tiyatronun müzik aleti sadece flüttür.

Ching Hsi'de (Başkent veya Peking tiyatrosu) piyesler, konuları itibariyle zengindir. Daha çok tarihsel ve mitolojik kahramanlar, imparatorların tahta geçişleri, gözdelerin çirkin rekabetleri, imparatoriçelerin kıskançlıklar, devlet büyüklerinin zulümleri, düşmanlara karşı savaşlar, kardeş kavgaları ve nihayet komutanların ihanetleri gayet canlı olarak bu sahnede gösterilir. Bu oyunlar edebi bir sanat eseri yaratmak gayesi güdülmeden aktörler tarafından yazılır. Piyesler uzun değildir, 1-2 sahnedir. Oyunda, muayyen kişilerle ilgili olayların başı ve hatta sonụcu toplu ve kısa olarak canlandırılır. Ve müzikal cümleler sınırlıdır, daima tekrar eder. Bu da seyirci kitlesinin bu müzik tekniğini daha kolayca anlamasını sağlar. Müzik aletleri ise telli enstrümanlardır.

Bu iki tiyatronun piyesleri genel olarak iki grup içinde toplanır:

\section{1- Askeri piyesler (Wu Hsi):}

Savaş oyunlarını ve tarihsel öyküleri içinde toplar. Çinliler bu temsilleri çok severler. Zira bunlar çok heyevan verici ve hareketli oyunlardır. Sahnede bayrakları dalgalandırarak çoşkun hareketler yapan kahramanlar savaş ihtişamının tüm deyimiyle canlandırırlar. Burada şarkı ikinci veyá üçüncü derecede gelir. Bütün parçalar savaş sahneleri haline konmuştur.

2- Sivil piyesler (Wen Hsi):

Bunlar sosyal olayları gösteren oyunlardır. Her günkü yaşantıyı yansıtırlar. Daha ziyade șiir ve şarkı üzerine kurulmuş oyunlardır.

Bu iki grup dışında, komediler ve mitolojik piyesler vardır. Komediler, akrobatik oyunlardan, güldürücü ve basit, şarkısız parçalardan ibarettir. Mitolojik oyunlar ise, tabiat üstü olayları anlatan ve kutsal insanların yaşantısına ait oyunları gösterir. Gerek Wu Hsi gerekse Wen Hsi piyeslerinin, hem gerçeğe hem de muhayyileye yani, mitolojiye ve folklöre dayandığını görüyoruz.

Ching Hsi tiyatrosunda iki müzik uslubu vardır. Bunlar Hsi-pi Erhhuang (Pi-huang da denir) usluplarıdır. Zamanla bu iki usluba birçok 
şekiller karışmıştır. Bilhasssa K'un Ch'ü müziğinin etkisi altında kalınmıştır. Bununla beraber, Ching Hsi'deki melodilerin çoğunun orijinal halk şarkılarından alındığını görüyoruz. Müzik burada sahne tekniğinin esaslı bir parçası olarak ele alınmıştır. Ve müziğin sahne efektine ilgisi olduğunu kabul eden aktörler, müzisyenlerle iş birliği yaparak sahne oyunlarına melodik şekiller katabilmek için müzikal kaynaklarlardan istediklerini seçip alırlar. Ve aynı zamanda bu oyunlar onların hergünkü yaşantılarından alınmış canlı, renkli ve hareketli tablolardır. K'un Ch'ü'de olduğu gibi sanatseverlere değil, sadece seyircilere hitab eder.

Bu tiyatroda pek çok telli müzik aletleri vardır. Bunların bazıları Çin'de veya Çinin dışında yaşayan kavimlerden alınmışlır. Sahne orkestrası için (Ch'ang-mien) şu müzik aletleri vardır (Bak. Resim 1-2) : ${ }^{23}$

Hu Ch'in: Bu Ching Hsi'nin başlica müzik aletidir. Kuzey kavimlerinden geldiği ve ilk defa Ming sülalesi zamaǹında kullanıldığı ileri sürülür. ${ }^{24}$ İki telli bir alettir. At kılından yapılmış bir yay ile çalınır. Gövde bambudan ve silindir şeklindedir. Yüzü deri ile kaplıdır. Sapı ise $40 \mathrm{~cm}$ boyunda ve bambudan yapılmıştır. Yukarı kısmında ise, iki tane tahtadan yapılmış ses anahtarları bulunur.

Erh Hu: Aynı katagoriye dahil ve ikinci derecede bir çalgıdır. Gövdesi altı köşelidir. Sapı $50 \mathrm{~cm}$ kadardır. Ses anahtarları $\mathrm{Hu}$ Ch'in gibidir.

Yüeh Ch'in (ay biçimi kitar): Arp ve ut ailesindendir. Gövđesi yuvarlaktır. Sesi daha yumuşaktır. Hu' Ch'in'e eşlik ẹder. Menşeinin orta Asyadan geldiği ileri sürülür. ${ }^{25}$

P'i-p'a: Çin tarihinde önemli yeri olan bir müzik aletidir. Menşeinin Batı Asyadan geldiği ve Çin'de ancak M. S. 6'ncı yüz yıllarda kullanıldığı kaydedilir. ${ }^{26}$ Birçok şekilleri vardır. Fakat daha ziyade armut biçimindedir. 4 ipek teli vardır.

23 Bak. René Bassier: Le enfants du jardin enchnatè. Taipei, 1965. s. 43-48.

24 Scott: s. $42-43$.

25-26 Scott: s. 44-45.

- Çin kaynakları P'i P'a'nın daha önceleri Çin'de kullanılmış olduğunu kaydeder. General Li Kuang kuçayı aldıktan sonra (M. S. 4'üncü yüz yıl), Çin'e gelen 'Kuça Müziği' yanında birçok da müzik aletleri vardı. Bunların arasında P'i P'a, org, flüt, kaval, davul, kung Hou, Pi Li gibi en önemli olanlardı T'o-pa sülalesi zamanında (m.s. 6'ncı yüz yıl) yine bu aletleri görüyoruz. Fakat Yüh Chin'e rastlamiyoruz (Bak. Tsı'h Yüan: c. II. s. 33 ve TPYL. Böl. 569. s. 2 a, 9 a). 
San Hsien: Ưç telli bir müzik aletidir. Mızrap ile çalınır. İkinci derecede bir alettir. Şekli ovaldir. Beden kırmızı tahtadan ve yılan derisinden yapılmıştır. Boyu $15 \mathrm{~cm}$ kadardır. Sapı ise $70 \mathrm{~cm}$ 'dir ve 3 tane ses anahtarı vardır.

Ti Tzu: Bambudan yapılmış bir flüttür. K'un Ch'ü'nün müziğinde de kullanılmıştır. Çinlilerin çok sevdiği bir müzik aletidir.

Tan P'i veyahut Hsiao Ku: Ǘ̧ ayak üstünde duran ve üstü deri ile kaplı bir davuldur. İki tane bambu değnekle çalınır. Çapı $50 \mathrm{~cm}$, derinliği $8 \mathrm{~cm}$ kadardır. Önemli bir çalgıdır. Orkestra şefi tarafından çalınır.

T'an $\mathrm{Ku}$ veyahut $\mathrm{Ta} \mathrm{ku}$ : sivil pieysler az, fakat askeri oyunlarda çok kullanılan bir davuldur. Buna $\mathrm{Hu}$ Ch'in eșlik eder. şekli bere biçimindedir. ve çeșitli büyüklüktedir. Öküz derisinden yaṕlmıştır. Kenarları siyah lâke kaplıdır. Üzerinde altun yaldızlı bir ejder resmedilmiştir. Bambu çubukla çalınır.

Pan: Çin sahne orkestrasının tipik bir müzik aletidir. Zamanı bildirir, ve orkestra şefinin değneği yerine geçer. Bu alet Tan P'i-ku'yu çalanın sol elinde bulunur. Kırmızı tahtadan yapılmış üç parçadan ibarettir. Uzunluğu $30 \mathrm{~cm}$ kadardır. Sert bir ses çıkarır.

Ta Lo: Bakírdan yapılmış büyük bir gonkdur. Sapı $30 \mathrm{~cm}$ 'dir topuzlu bir değnekle çalınır.

Hsiao Lo: Küçük bir gonkdur. Aktörün gelişini bildirir. Şarkı söylenirken kullanılmaz. Askeri piyeslerde, savaş sahnelerinde ve durma hareketlerinde çalınır.

Hsing: Bu alet iki küçük prinç kaptan ibarettir. Birbirine bir kordonla bağlıdır. Birbirine vurularak ses çıkarır. Trajik havalarda davulla beraber kullanılır.

Yün-lo: Seyrek kullanılan bir alettir. Törenle ilgili piyeslerde ve diğer aletlerle birlikte çalınır. 10 küçük gonktan ibarettir. 9 tanesi tahta bir çerçeveye asılıdır. 10'uncusu ise çerçevenin üstüne tespt edilmiştir. Her gonk çeşitli büyüklüktedir. Başka başka sesler çıkarırlar. Tahta bir değnek ile vurulur.

Po: Pirinçten yapılmış küçük bir zildir. Askeri piyeslerde, törenlerde ve imparatorun sahneye girişinde gonkla beraber kullanılır.

So Na: Ağız kısmı pirinçten, diğer tarafları kırmızı tahtadan yapılmış huni şeklinde bir borudur. Üst kısmında 7, alt kısmında ise 1 delik vardır. 
Orkestra sahnede şu şekilde yerleştirilmiştir: Sağda orkestra şefi, ortada Tan P'i Ku'yu çalan kimse bulunur. Bu aynı zamanda Pan'ı kullanır. Solda Erh Hu ve onun yanında Po'yı çalanlar yer alır. Bunların önünde solda $\mathrm{Hu}$ Ch'in, sağda ise Hsiao'Lo'yu çalanlar bulunur. Davulcunun ve şefin hemen arkasında San Hsian'i yöneten oturur. Solunda Yüeh Ch'in, sağında ise Ta Lo'yu çalanlar yer almıştır.

Artistlerin sahneye giriş (Shang Ch'ang) ve çıkışları (Hsia Ch'ang) özel bir konuşma ve özel bir orkestra parçasının eşliği ile yapılır. Daha ziyade gonk ve davul çalınır. Bunlardan başka bu giriş ve çıkışlarda, yani sanatçının şarkısına başlamadan önce veya iki şarkı arasında telli aletlerin eşlik ettiği müzik parçaları da çalınır. Bu aktörün şarkısının ve aksiyonlarının kontrolü için yapılır. Monolog ve diyaloglardan sonra her türlü heyecanları anlatmak için şarkı söylenir. Aktör şarkıya başlıyacağı zamana sesini yükseltir ve ayağını yere vurur ve kollarının yenleri ile özel bir işaret yapar. Orkestraya asla bakmaz. Bakarsa, müzisyenlerin yanlış yapmış olduğu anlaşıllır.

Orkestraya eşlik eden ve 'Giriş' 'Çıkışları' gösteren müziklal parçalardan birkaç örnek verelim:.

Ta Ch'ao Shang: Imparatorun veyahut büyük bir memurun 'Girişi' için çalınır.

Hsiao Lo-man-erh-t'ou Shang: Ün kazanmış bir kişinin girişini ifade eder.

Hsiao-lo K'uai-ch'ou-t'ou Shang: Başka bir memleketten gelen bir bilginin sahnede görünüşünü gösterir.

Ta-lo-yin-lo Shang: Periler, ruhlar, hayvanlar için kullanılır.

Ta-lo-ssu-chi-t'ou Shang: Askeri piyeslerde 4 generalin beraber görünüşü için çalınır.

Feng-ju-sung Hsıa: Bir genaralin adamlarına savaşmaları için verdiği emri anlatır.

Chou-nu-erh-hsia: Askerlerin savaşa gidişini gösterir.

Nan-lo Shang: Komik veyahut kötü bir kişi için çalınır.

Chi Ku Shang: Savaş piyeslerinde ok kullanıldığı zaman davulun çaldığ 1 bir parçadır.

Hsiapo-lo-lan-pan-to-t'ou Shang: İyi karektrli ve erdemli kadının evinde olduğunu gösterir. 
Cha Shang: Kötü karakterli bir kişiyi, bir hırsızı anlatır.

Wu-ma-ch'ang-erh - shui - hsia: Birçok generallerin uzaklardan gelerek imparatoru ziyareti için çalınır.

İ-fang-chiang-erh-shui-hsia: Denizdeki savaşı anlatır.

Wei-shang-hsia: Oyunun bittiğini gösterir.

Aktör ve rolleri: Tiyatroya çok düşkün olan Çin Halkı çok güç beğenir. İlk defa sahneye çıan genç bir aktör seyircilerden asla teşvik eđici bir davranış alamaz. Zira yeni sanatçı sosyal geleneklere bağlı bir sahnede, bir sahne karakteri yaratmak zorundadir. Kendisinin, taklitten uzak kendi kişiliği ile birlikte yeni bir ruh, yeni bir yaşantı getirecek bir yeteneğe sahip olması gereklidir. Böyle bir yeteneği gösterdiği zaman seyirci onu takdir edecektir.

Çin aktörü uzun ve sıkı bir çalışm devresi geçirir. 7-12 yaşları arasında tiyatro okuluna gírer . 6 yıllık eğitim devresinde sıkı bir disiplin altında çalışır. Bu disipline karşı gelenler ağır bir şekilde cezalandırılır.

Okulun ilk çağları̀nda Çin aktörü Batıdaki bale oyuncularının gördüğü eğitimi yapar. Genç vücudun fiziksel bir kuvvet kazanması gerekir. Bundan sonra öğrencinin ileride hangi rollerde uygun olabileceği kararlaştırılır. Sesinin ahengi, yüzü, vücut yapısı çok önemli faktörlerdir. Oynıyacağı role göre yetiştirilen öğrenci 6 yıl sonra okuldan mezun olur. Bir yıl kadar okul temsillerinde oynamak zorundadır. Burada kabiliyetini gösterme fırsatını bulmuş olur.

Aktörlerin rolleri 4 çeşittir. Sheng, Tan, Ching ve Ch'ou.

Sheng: Erkek rollerini içine alır. Bilginleri, devlet adamlarını, kahramanlar, kumutanları temsil eder. Bunlar yüzlerine asla makyaj yapmazlar. Fakat herzaman için sakal kullanırlar (Resim 3). Sheng rolleri 'Wu Sheng (savaş, akrobatik sahneler) ve 'Wen Sheng' (şarkılı oyunlar) olmak üzere iki çeşittir. Bazen bu ikisini içine alan piyesler vardır. Bunlara Wen Wu Sheng denir. Wu Sheng sinıfinda 3 tip vardır. Wu-lao Sheng tipi, yaşlı bir savaşçıdır. daima beyaz bir sakal takar. Ch'ang K'ao tipi, general ve yüksek rütbeli silâhşörlerdir ki, bunlar 4 bayrak ve silahlarla ve sonra omuzlarına tutturulmuş filamalarla donatılmışlardır (Resim 4). Tuan Ta sınıfındaki sanatçılar, siyah elbiseler ve düz, yumuşak çizmeler giyerler. Kılıç kullanmakta mahirdirler. Bir kedi çabukluğu ile sıçrarlar. Şarkı söylemezler, haydutları, hırsızları, veya aşağı tabakadan kimseleri canlandırırlar.

Wen Sheng sınıfı ikiye ayrılır. Hsü Sheng Ve Lao Sheng.... Uzun süre şark1 söyliyecek bu sanatçılar güzel bir bariton sese sahip ol- 
malıdır. Sesini pantomin ve jestleriyle gayet iyi ayarlaması gerekir. Bakışları ve parmaklarının bükülüşü müziğe uygun olmalıdır.

Hsü Sheng: Bu sınıfı orta yaşlı bilginler ve devlet adamları temsil eder. Lao Sheng'ler, yaşlı ve fakir sınıfa mensup kimseleri ve köylüler ve mülk sahiplerinin kahyalarını canlandırırlar. Bunların şarkıları derin bir ızdırabı yansıtmaktadır.

Hsio Sheng: Ekseriya genç adamları temsil edenlerin sınıfıdır. Prenslerin aşklarını, fakir bilginleri ve züppeleri canlandırırlar. Asla sakal takmazlar. Bunlar üç tiptir . Shan-tzu Sheng tipi: İyi bir aileye mensup bir şehirlidir. Eğlenceli oyunlar yapar. Chi-wei Sheng tipi: Genç bir silâhşörü veya bir prensi canlandırir. Başına uzun bir sülün tüyü takar. Ch'ung Sheng tipi: Fakir bir bilgin veyahut sıkıntıda olan genç bir adamdır. Bu ekseri karekter oyunlarda yer alır. Bunun için çok iyi rol yapması ve güzel bir sese sahip olması icabeder. Hsiao Sheng', K'un Ch'ü tiyatronun en önemli bir rolüdür. Bunu ancak en başarılı sanatçılar oynar. Tekniği çok başkadır. Çünkü erkek rollerinin sert havası ile kadın rollerinin yumuşaklığını biribiri içinde eritmek sanatçı için zor bir iştir. Bunun yanında ses tekniği de çok önemlidir (Resim 5).

Tan sınıfı: Burada aktörler daima kadın rollerine çıkarlar. Onların işi, bir kadın karekteri yaratmaktır. Tekniği çift sembolizm üzerine kurulmuştur. Yani oyuncu sahne tekniği yanında bir kadın olduğu inancını yaratmak zorundadır. Batılıların gözünde Çin tiyatrosu realistik değildir. Biçimsel bir sembolizme dayanır. İşte Tan artistinin tekniğinin gelişmesi bu sembolizm şekilleriyle olmuştur. Onlara göre, oyun bir taklitten ibaret değildir. Seyircilerin gözünde, kadını canlandıran esas noktaları yani, o zamana göre idealleştirilmiş sembolizmi ortaya koyma maharetidir (Resim 6).

Kadın rollerine çıkacak erkeklerin, iyi bir sese, çehre güzelliğine sahip olmaları gereklidir. Yumuşak bir ses ve görünüş bir sanatçıdan istenen başlıca meziyetlerdir.

Yüan sülalesine (Moğol) kadar kadın rollerini hep erkekler yapmışlardır. Yüan'lar zamanında bir ara kadın sanatçılar görülmüşse de bunlar, ahlak bakımından iyi karşılanmamıștır. Mançu hanedanı zamanında ise, hem kadın hem de erkek artistler sahnede yer almışlarlardır. Mançu imparatorlarından Ch'ien Lung tiyatroya çok önem vermişti. Fakat kadınların sahnede yer almalarını yasaklamıştı. $\mathrm{O}$ zaman kadın rollerini yapacak kişilerin yetiştirilmesine büyük bir gay- 
ret gösterildi. Yumuşak bir se s ve görünüş kadar teknik de önemli idi. Böylece teknikde de bir takım değişiklik ve yenilikler oldu. Sonuç olarak, çok iyi oyuncular yetişti. Öyleki kadın sanatçılar bile bukadar iyi rol yapamazlardı. Mei Lan-fang en ünlü olanlarındandır.

1911'de Mançu sülâlesinin devrilmesi ve Cumhuriyetin kurulmasiyle kadın oyuncular da sahneye çıkmaya başladılar. Büyük başarılar kazandılar, ün yaptılar. Bunlardan Hsüeh-yen-chin en başta gelir.

Ching sınıfı: (Resim 7) Ching rollerini yapacak sanatçılar yüzlerini daima boyarlar. Zira oynadığı rolle makyajın büyük bir ilişkisi vardır. Makyaj kaidelerinden iyi anlayan bir kimse oyuncunun karekterini bu yüzdeki renklere ve şekillere bakarak anlar. ${ }^{27}$ Çin tiyatrosunda yüzü boyma aynı zamanda büyük bir teknik iş sayılır. Zira oyundaki kişilik ancak boyalarla sembolize edilir. Sanatçılar, kahraman askerleri, kurnaz ve kötü devlet adamlarını, namuslu hakimleri, Tanrıları, tabiat üstü varlıkları temsil etmek üzere yüzlerine makyaj yapmak zorundadırlar. Bu kişiler döğüșürken kuvvet ve kudreti göstermek isterler. Boyah yüzlerinden başka omuzlarındaki apuletli jaketleri, yüksek çizmeleri onların ihtişamını artırır. Bu rolleri yapacak olanların makyoja uygun yüzleri ve bilhassa geniş alınları olması gerekir. Bunlardan başka uzun boylu ve gür sesli olmalıdırlar. Burada ses tekniği de önemlidir.

Ching sınıfı oyunları 3 bölüme ayrilır. Cheng Ching: Önemli ve iyi kişileri canlandırır. Bunların çok iyi şarkı söylemeleri gerekir. Fu Ching: Kötü karekterli kişilerdir. Burada şarkıya pek fazla önem verilmez. Daha ziyade konuşmaların ve aksiyonların iyi olmasına dikkat edilir. Sonra, yüzünün ifadesi, bakışları da önemli rol oynar. Wu Ching: Bu oyuncular döğüş, jimnastik üzerinde kendini gösterir. Bazı yerlerde şarkı, bazı yerlerde ise akrobasi ve iyi konuşma aranır.

Ch'ou sınıfı: Bunlar Çin sahnesinin palyaço ve komikleridir, fakat budala tipler değildir. Ciddi ve kötü kişileri canlandırırlar. Burada hergünkü lehçe konuşulur. İsterse irticalen söylemekte serbesttir, Kendiliğinden gelen nükteli sözler ve jestler onun tekniğidir. Bunların içinde mimik ve akrobatik mahareti de vardır. Makyaj olarak, gözlerinin etrafında ve burnunda beyaz boyalar vardır. Bazen buna ilâve olarak siyah çizgiler konur (Resim 9). Bu oyuncular kadın rollerinde ekseriya kötü bir kayınvalideyi veya dünürü canlandırırlar.

27-Makyaj: Kırmızıya boyanmış bir yüz, doğruluğu ve onurlu oluşu gösterir. Beyaz pudralı bir yüz ise, hain, fakat kuvvetli bir insanı, siyaha boyanmış bir yüz de dürüst fakat zayıf karakterli bir kişiyi canlandırır (bak. Resim 8) ve

- Rene Bassier: Aynı kitap. s. 31. 
Ch'ou sınıfı ikiye ayrılmıştır. Wen Ch'ou: Adi rolleri içine alır. Bunlar hizmetçiler, mahpuslar ve saire kişilerdir. Wu Ch'ou. Askerlerdir. Bunlar düğüşürler, ata binerler, ve akrobasi hareketleri yaparlar.

Tiyatro binası ve dekorlar: (Resim 10) Eski çağlarda tiyatro binaları tapınaklara aitti. Bina taştan yapılmıștır. Damları gayet süslüdür. Sahne yerden yüksek olarak yapılmış bir platforum şeklindedir. Üç tarafı açıktır v perde yoktur. Halk mabedin avlusunda ya oturur veyahut ayakta seyreder. Bu sahne sonradan gerek saraylardaki ve gerekse șehir tiyatro sahnelerinin protipi olmuștur. Tapınak sahnelerinden sonra, halk tiyatroları geçici olarak kurulmuştur. Tahtadan yapılmış olan bu sahnelerin bambu direkleri vardır ve kolayca kaldırılabilir. Şehirlerdeki daimi tiyatro binalarının menşei çay evleridir. Mançu sülalesi zamanında sahne tipi bu çay evlerinden alınmış ve geliştirilmiştir. Peking'deki yazlık saraydaki sahne böyle bir sahnedir. Yalnız bu üç katlıdır. ${ }^{28}$ Sarayın himayesinde olan bu tiyatro yalnız saray halhalkının eğlenmesi için yapılmıştır. Halktan kimse buraya giremezdi. 1911'den sonra bu çeşit eski tiyatro binaları yerine modern tiyatro binaları yapılmıştır.

Dekorlar: Sahnede bizim dekor diyebileceğimiz bir şey bulunmaz. Dekor olarak ortaya konan şeyler gayet semboliktir, yabancılar bir şey anlamaz. Örneğin : Bir değnek bir atı, üzerine tekerlek resmi yapılmış bir çift bandıra bir arabayı temsil eder. Aktör kapıyı kapamak isterse ellerini birleştirir. Ellerini açmakla kapıyı açmış olur. Sahneye püsküllü veya tüylü bir değnekle girerse ata biniyor demektir. Değneği yere atar veya uşağına firlatırsa attan iniyor demektir. Üzerine balık resmi yapılmış bir bayrağı sallarsa, bu firtına veya sel baskını olacağına bir işarettir. Elleri alnında olduğu halde koșarak sahneye gelen aktör şiddetli bir yağmurun gelmekte olduğunu anlatır. Kuvvetle nefes alırsa çok içki içtiğini ifade eder. Takma sakalını üfler ve başını sallarsa kızgın olduğunu anlatmış olur.

Bir masa mahkemeyi, lokantayı veya bir memur masasını ve masa üstüne konmuş bir sandalya tahtı ifade eder. Masaya tırmanmak tepeye tırmanmak demektir. Masaya çıkan general etrafı denetliyor demektir. Masa yanında bir sandalya bir dağı temsil eder. İki bambu değnek arasına getirilmiş bir kumaş bir şehir duvarını gösterir. Bir im-

28-Peking'deki sarayın bahçesindeki tiyatro binasının üç katlı yapılmasında bir gaye gözetildiği ileri sürülür. En aşağı katta kötü ruhlar, ikinci katta ise göksel varlıklar yer almış oluyordu (Bak. Scott. Aynı eser. S. 219). 
parator daima ejderli sarı ipek bir elbise ile görünür. İmparatorun adamları uzun elbiseler giyerler. Hizmet edenler aşağı tabakadan kimseler ise kısa jaket ve.pantolon giyerler. Yüksek rütbeli bir genaral arkasına dört bayrak takmış olarak görünür..

Sarayın himayesinde olan saray tiyatrosunun her türlü masraflar1nı saray bütçesi karşılar. Fakat şehir ve halk tiyatrolarının masrafları ise oranın zenginleri tarafindan ödenir. Genel olarak giriş parası diye bir şey yoktur. Halk istediği zaman gelir, sıralara ve msaların etrafındaki sandalyalara oturur, yer içer ve oyunu seyreder. Yalnız içtikleri çayın parasını (Ch'a ch'ien) öderler. Zamanla bu adet kalkmış ve halk oturdukları sandalyeler için muayyen bir para ödemeğe başlamışlardır. Bununla beraber, bazi yerde eski adeti devam ettiren tiyatroların (örneğin, Nanking'de Fu-tzu Miao'da) 1948'larda bile varolduğunu görüyoruz.

\section{Halk Tiyatrosu:}

Yüksek tabakanın tiyatrosu sayabileceğimiz K'un Ch'ü ve Ching Hsi tiyatrolarının yanında konuları ve ruh yönünden çok farklı olan ve onların hemen her günkü yaşantısını gösteren bir halk tiyatrosu da vardır. Bu tiyatro büyük yetenekleri geliştirecek bir ortam bulamamakla beraber, uzun yıllar orijinalitesini ve canlılı̆ıını kaybetmiyerek halk için en büyük bir eğlence kaynağı olmuştur.

Halk tiyatrosunun temelini teşkil eden Yang-ko'lar (nebat şarkıları), halk tiyatrosunun en canlı örneklerinden biridir. Yank-ko'ların menşeinin, Sung sülalesinin (12-14'üncü yüz yıl) ünlü şairlerinden Su Tung-p'o'nin yazdığı şiirler olduğu ileri sürülür." Şair , Ting vilaytini yönettiği zaman oradaki halkın pirinç tarlaları içinde çalıştığını görmüş, onların yorgunluğunu giderecek ve güçlüğü unutturacak şarkılar yazmış. Bunları bilhassa pirinç ekme zamanında söylemelerini anlatmış. Çok geçmeden bu şarkılar bütün Ting vilayetine yayılmış ve köylüler yazı bilmediklerinden ancak ağızan ağıza nakledilerek bu günkü şeklini bulmuştur. ${ }^{29}$

Fakat, Yang-ko'ların menşeinin böyle 12'inci yüz yıl gibi geç bir tarihe konulmıacağı kanaatindeyiz. Zaten Su Tung-p'o da Wu Chang şehrinden geçerken köylülerin kamıştan bir ata (Yang-ma) bindiklerini ve bunula gezdiklerini anlatır. Amma burada şarkı söylediklerinden hiç bahsetmez. ${ }^{30}$

29-Ting-hsien Yang-ko hsüan: F. H. Lee. F. S. W. Chang. 1933. s. 1-9.

30-Chi-chu-fei-lei Tung-p'o Hsian Shen-shıh: Ching-chin Tung-p'o Wen-chishuliao. böl. 24. s. 61 (Shanghai, Commercal press). 
Su Tung-p'o Wu Chang'da vali iken, Yang-ko'lara benzer bazı oyunlara rastlamış olabilir. Belki bunlar Ekin Tanrısına yapılan törenlerle ilgili idi. Belki de basit bir tiyatro oyunu idi. Şairin bunlardan faydalanıp şiirler yazbileceği ihtimal dahilindedir.

Yang-ko'ların çoğu kısa şarkılardır. Ko-chü bir nevi şarkı şeklinden alınıp temsil haline konmuştur, Uslubu da çok basittir.

Elimizde mevcut Yang-ko'lar 6 gruba ayrılmıştır ve hepsi 48 sahneden ibarettir.: ${ }^{31}$

1- Aş่k grubu: Kadın-erkek arasındaki aşkla ilgili oyunları içine alır. Burada, 'en iyi at çift eğere konmaz, namuslu bir kadın da iki defa evlenmez' düşünüşü ifade edilmek istenmiştir. Sonra burada, yüksek öğrenim yapmış genç kızların ünlü kişilerle hatta imparatorla evlenmek istedikleri gayet açık olarak gösterilmiştir.

2- Aileye itaat ve dürüstlük: Bu gurup 'Nebat şarkı'larından, Çin toplumunda aileye itaatin ve sonra dürüst olmanın nekadar önemli olduğunu anlıyoruz. Anaya babaya bağlı bir genç herkes tarafından saygı ile karşılanır. Bu aynı zamanda Göğe, toprağa, ruhlara ve şeytanlara da etki yapar. Sonra, dürüstlük dul kalan bir kadın için esastır. Ve çin toplumunda 'yüksek erdemli' olarak nitelenir.

3- Karı koca arasındaki ilişki: Burada, kadın erkeğin kölesi, malıdır. Erkek de onun efendisidir. Aralarında eşitlik gözetilmez. Erkek istediği zaman karısını boşar. Halbuki bu hak kadına verilmemiştir. Kadının çocuğu olmadığı zaman da erkek onu boşayabilir. Yahut başka bir kadın alabilir. Bu ekseri kayınvalidenin isteği ile olur. Erkek anaya babaya olan bağlılığından dolayı annesine karşı gelemez ve onun isteğini yerine getirir. Kadının kocasından ayrılması Çin toplumunda büyük bir ayıp sayılır. Bunun için iki sonuca katlanmak zorundadır. Ya kocasının başka bir kadınla evlenmesine razı olur, veyahut da saçlarını keserek rahibe olur. Bu oyunlarda yine, kadinin kocasina sadik olmadığı da görülür.

4- Kayınvalide ve gelin arasındaki ilişki: Bu grup oyunlarda genç kızı evlenmiş ve kocasının evinde gösterir. Kayınvalidenin geline karşı büyük bir otoritesi vardır. Gelin önce kayınvalidesinin sonra da kocasının emirlerini yerine getirmek zorundadır. Kendisi hiçbir şekilde istediği gibi iş göremez. Ailesi ise kızlarının durumu ile hiç ilgilenmezler.

31-Bak. Ting-hsien Yang-ko -hsüan . s. 3. 
5 - Şakalar, alaylar, ve eğlencelerle ilgili oyunlar bu gruba içinde toplanmıştır.

6 - Çeşitli konuları içine alan grup: Burada, saflığını korumuş dış etkilerden uzak, karışmamış mahalli Yang-ko'ları da bulabiliyoruz.

Bütün bu 6 grup Yang-ko'larda yüksek tabakaya hitap eden, onun ruhunu yansitan bir sanat göremiyoruz. Konular onların her günkü yaşantısını tam manasiyle canlandırıyor. Dış olayların etkisinde kalmışlarsa da bu, müspet yönden olmuş ve küçük oyunların büyük temsiller haline gelmesine yardımı olmuştur.

Bu grupların örgütlenmesi şu șekilde olmuştur: Her köyden iyi şarkı söyleyenler bir oyun grubu teşkil ederler. Buna bağhı birçok gruplar vardır. Bir grup elbiseleri diker, giydirir, değişirir ve makyaj yapar, müzik çalar veya her nevi süs eşyası satar.

Bu temsillerde oynayanlar aynı zamanda çift sürerler, tarlada çalışırlar veya başka bir işle meşgul olurlar. Bir kısmı da temsiller için öğrenci yetiştirirler. Öğrenci yetiştirmek için hiçbir metodlanı yoktur. Dersleri sözlüdür. Artistler piyese pek tabi olmazlar. Kendiliklerinden birşeyler katarlar. Pek tabii bunlar profesyonel sanatçı olamazlar.

Müzik aletleri basittir. Gonk, davul, çan, zil, dört çeşit çembaldir. Yaylı aletler yoktur. Sabit bir sahne yeri de yoktur. Herhangi bir yerde, bir tapınağın önünde, bir pazar yerinde temsillerini verirler. Bu temsilleri her kes ayakta seyreder, zira oturacak yerleri yoktur. Bazı köylerde seyirciler için masalar konmuştur. Burada yerler içerler ve oyunu seyrederler.

Temsiller için gereken masrafları köylüler karşılar. Bu köylülerin mâli durumuna göre tespit edilmiştir. İsteyenler para vermezler, yerine yiyecek verirler.

$\mathrm{Bu}$ oyunlar bilhassa kadınlar için iyi bir eğlencedir. Zira onlara başka bir yere gidemezler. Bu temsiller onlar için her bakımdan fayda sağlar. Başka köylerdeki akraba ve ahpaplarını davet etmek veyahut ziyaret etmek firsatını bulurlar.

$\mathrm{Bu}$ temsiller en çok on gün devam eder. Her yıl yeni yılı kutlamak için ve hasat zamanı Ekin Tanrısına şükranlarını sunmak amacıyla yapılır. Bundan başka 'Köy Tanrısına, da temsiller verirler. Bu şekilde bu oyunlar bir eğlence olmakla beraber dinsel bir görevi de yerine getirmek için yapılmaktadır. 
Burada gerek klasik ve gerekse halk tiyatrolarının Çin'de tam manasiyle millileşmiş ve halk kitlesinin derin ilgisini çekmiş olduğunu görüyoruz. Ve uzun yillardanberi bu güne kadar yaşaması dış etkilerden, taklitten ve sunilikten uzak kalarak özelliğini koruyabilmesinden ileri gelmektedir. Batı sanatından çok farklı olan Çin tiyatrosu. yalnız kendine öz varlıkları halkın önüne serdiği için yüz yıllarca ayakta durabilmiştir.

Yang-ko temsillerinden biri olan 'Altın tuğla öyküsü' (Chin-shıh $\mathrm{Ku}$ ), Çin halk tiyatrosunun tipik bir örneğidir. Bu bakımdan bu oyunu burada göstermeği faydalı bulduk.

'Altın Tuğla öyküsü', Chu Ying-t'ai ile Liang Shan-po adındaki iki gencin aşk öyküsünü anlatır. Ting vilâyetinin oyun haline konmuş Yang-ko'larının aşk grubuna dahildir. ve erkek çocukları olmayan bir ailenin, kızlarına erkek giysileri giydirip okula göndermelerini anlatır. O çağlarda okula yalnız erkek çocuklar giderdi. Kızların öğrenim yapması yasaklanmışı. Bu öykü, o zamanki Çin toplumunda kadının bir yeri olmadığını ve öğrenim yapmasının da imkansız olduğu teması üzerinde işlenmiştir.

Oyun manzumdur. Uslubu çok basittir. Dil de tam bir halklılık gösterir. Gramer kaidelrine hiç önem verilmemiştir. Satırlardaki kelime adedi 2-14 arasında değişir. Fakat genel olarak 7-7, 7-8 kelimeden ibarettir. Mısraların dizilişi kıta ve beyit şeklinde olmadığı gibi muntazam bir dizi halinde de değildir. Kafiye ise, Çin şiirlerinde görülen (5'ler ve 7'ler şïrinde) muayyen bir biçimde değildir. Çeşitli kafiye şekilleri birbirine karışmıştır.

'Altın Tuğla' öyküsünün biribirinden farklı metinleri vardır. Bunlar elimizdeki metinler karşılaştırdığımız zaman, gerek başlık ve gerekse kişi adlarının aynı olmadığını görürüz. Bundan başka öykünün konusunda da ayrılık vardır. ${ }^{32}$

Bu öykünün menşei 4'üncü yüz yıla götürülür. Fakat bunun 1l'inci yüz yıldanberi tiyatro parçası haline konduğu tespit edilmiştir. Ve oyunun içindeki diğer değişikliklerin 17 'nci yüz yılda yapıldığı anlaşıllyor. ${ }^{33}$

32-Mukayese et: Bizim Metin (Arkada gösterilmiştir). Ve,

- W. Eberhard, Chinese Fairy tales and folk tales. 1937 London. s. 187-191.

- W. Eberhard. Typen Chinesischer Volksmarchen, 1937. Helsinki. s. 265-266 (Burada Chu Ying-t'ai olarak geçer).

- Chekiang-ti Min-chien Hsi-ch'ü (yazan. Wang Shıh - han), Chekiang. 1937 s. 6

33-W. Eberhard: Typen chinesischer Volksmärchen. s. 266. 
$\mathrm{Bu}$ temsilin birçok kaynaklarda yer aldığını görüyoruz. ${ }^{34} \mathrm{Bu}$ gün bile Hong Kong'da ve diğer memleketlerde oynanmaktadır. ${ }^{35}$ Burada bu oyunun halk arasinda nekadar populer olduğunu anlıyoruz. veriyoruz:

Çin halk tiyatrosunun en sevilen oyunu olan bu piyesi aşağıda

\section{Altın Tuğla Öyküsü}

\section{(Chu Ying-t'ai ve Liang Shan-po)}

Shan-po söylüyor: 'Bütün gün okulda kitap okuyor ve ödev yapıyorum. Onbin satır okumazsam imparatorun yanına nasıl gidebilirim?

Benim adım Liang Shan-po'dır. Babamdan 'Yüksek Dağ'da öğrenim yapmam için emir aldım. Burada öğrenim yapmanın nekadar güç olduğunu şimdi anlıyorum'.

Shan-po (şarkı ile): Liang Shan-po 'Yüksek Dağ'da oturuyor. Birdenbire aklına birşey geliyor. Eskiden Chou imparatoru Wu Wang tahta geçtiği zaman büyük bir ferman çıkartmıştı. Herkesin okula gidip öğrenim yapmasını emrediyordu. Babam imparatorun bu fermanını görüyor. Eve geldiğinde beni çağırıyor ve diyor ki, eğer oğlumun mun ailesine karşı saygısı varsa, Yüksek Dağ’a öğrenim yapmağa gider. Eğer saygısı yoksa, sokaklarda koşup oynar'.

Tabii babamın isteğini kabul ettim. Okul çantamı alarak 'Yüksek Dağa' geldim. Evden ayrıldığım zaman '4'üncü aydı. Şeftali ve zerdali çiçekleri açmış, bahçeleri doldurmuştu. Yolda bir bambu ormanından geçiyordum. Soy adı Chu, kendi adı Ying-t'ai olan birine rastladım.

34-Bu oyun için diğer kaynaklar:

- Ting-hsian Yang-ko. böl. 1. (Hopei, Ting-hsien).

- Chu Ying-t'ai Ku-shlh Chi.

- Kuei-chi İ-wen (Chekiang, Shao-hsing).

- Hai-lung-wang. s. 99-107 (Kuangtung, Wen-yüan).

- Min-su. 38. s. 8-13 (Güney Fukien).

- Hunań Ch'ang-pen T'i-yao. s. 22-23 (Hunan).

- Min-chien Chuan-shuo II., 44-52.

- Chao-hsien Min-cihien Chuan-shuo. s. 107-116 (Kore).

- Hung-hua Nü. s. 1-9 (Kuangtung, Hua - hsien).

- Min-su. 108. s. 43-44.

35-Bak. Sergei Obraszow. Das Chinesische Theater. Hannover, 1965. s. 84 (bk. Resim 11). 
İkimizde yürüyerek, konuşarak birbirimize arkadaşlık ettik. Ve kardeşlik yemini verdik.

O bana oturduğum yeri sordu. Ben de Yingt'ai ailesinin yaşadığı memleketi sordum. Soy adımın Liang ve kendi adımın Shan-po olduğunu söyledim. İkimiz de 'Yüksek Dağ'a öğrenim yapmağa gidiyorduk'.

Pai-jui Lien söylüyor (şarkı ile): Lekesiz, bembeyaz bulutlar göğü kaplamış. Kocamla ben 'Dağ'da öğrencilere ders veriyoruz. Kocam şimdi. 'Dağ'in eteğinde misafirleriyle şarap içiyor. 18 öğrenciye bakacak kimse yok.'

Pai-jui Lien yatak odasından çıkıyor, uzakta olmayan ders salonuna giriyor. Öğrencilerin derslerine çalıştıklarını görüyor.

-'Kuyudan su çekme ve odun taşıma sıra ile. Bu gün sıra kimde?'

Shan-po (şarkı söylüyor) öne doğru eğilip bir reverans yapıyor: 'Öğretmeninin sözlerini işittim. Bu gün odun taşıma sırası bende değil.'

Yin - t'ai (şarkı söylüyerek içeri giriyor): 'Bu gün nöbetin bende ololması gerekiyor."

Pai-jui Lien (şarkı söyliyerek): 'Peki, bu günkü nöbeti sana yaptıracağım. Şimdi dışarı çık ve su değneklerini yatak odamdan getir.'

Ying-t'aı (şarkı ile): 'Ben öğretmenim için kuyudan su çekeceğim'. (Su değneklerini kaldırarak omuzuna koyuyor, kovaları alıp gidiyor). Bayan Jui Lien ona gizlice bakıyor. Onun bir erkek çocuğa benzemediğini ve bir kadın kadar güzel olduğunu görüyor.

Ying-t'ai kuyuya gidiyor. Su değneklerini indiriyor. İpi kovanın zincirine bağlıyor ve kovayı sarkıtıyor. Kova, aç bir kaplanın payını yediği gibi suları yutuyor.

Yıng-ta iki kova su çekiyor, yorgun düşüyor, mendili ile yüzünü serinletiyor.

Jui Lien (öne doru geliyor, parmağını kaldırarak kötü sözler söylüyor. Öğrencisini kolunđan tutarak azarlıyor): 'Sana su çekme görevini verdim. Sen ise oyun oynamak istiyorsun. Öğretmenini dinlemedin, kötü iş yaptın. Bunun için eline 40 değnek vurulacak. Bu gün artık su çekmiyeceksin.' (Öğretmen su değneklerini alıyor).

Ying-t'ai (şarkı söylüyor): 'Öğretmenimin eşinin kovaları yere koymasını rica ettim. Ben dinlenerek su taşıyacağım.'

Jui Lien (şarkı söylüyor): 'Su getirtmek veya getirtmemek bana ait birşey. Ben şimdi yatak odama iplik bükmeğe giidiyorum.' ve uzaklaşarak gidiyor.) 
Ying-t'ai (şarkı söylüyor): 'Ben öğretmenimin eşi için kuyudan su çekeceğim (tahta kovayı alarak hemen zincire takıyor. Küçücük ayaklariyle büyük adımlar atıyordu. Dümdüz yolda yere düştü. Ve sular etrafa dağıldı. Çizmeleriyle birlikte mavi elbisesi de islandı).'

'Çizmelerimin ıslanmasına aldırmıyorum. Yalnız küçük ayaklarımın 1slanmasından korkuyorum. Kızıyorum, hem çok kızıyorum. Ailem doğru birşey yapmadığı için kızıyorum. Erkek çocukları yoksa, bir erkek evlat için Tanrıya yalvarsınlar. Niçin bir kızı erkek yerine koydular. Ben öğrenim yapmanın iyi yönleri olduğunu biliyorum amma, burada su çekmenin zorluklarını bilmiyordum.' Ying-t'aı gerçekten ailesine kızıyordu.

Shan-po (şarkı söylüyor): 'Ben Shan-po, dersanede çok sıkıliyorum. Kardeşim su çekiyor. Hâlâ dönmedi? Kuyuya kadar gidip bir bakayım.' (Hemen dersanedn çıkıyor. Kuyu uzakta değil, yakında idi.) 'Kardeşimin göz yaşlarının yağmur gibi aktığını görüyorum. Kardeşime beklemesi için sesleniyorum. Ağabeğin senin yerine su çekecek. 'Shanposu değneklerini alıp gidiyor.

Ying-t'a1 (şarkı söylüyor): 'Kalbim , sevinçle dolu. Ağabeyim önceki gün benim yerime su çekmişti. Bu gün de yine benim için su çekecek. Eve döndüğümüz zaman evlenmemiz iyi olacak.' Yint-t'ar bunları kalbinden geçirmişti. Başkaları duymamıştı.

Shan-po suları getirdi. Mutfağa girdi. Ve suları yere bıraktı. 'Şimdi hemen gitmeliyim. Öğretmenimin görmesi iyi olmaz.' Shan-po uzaklaşıyor.

Jui Lien (şarkı söylüyor) (Öne yaklaşıyor, parmağını kaldırarak bağırıyor): 'Seni azarlamalıyım. Sözlerimi iyi dinle. Sen başkası için su çektin. Doğruyu söylersen seni bırakacağım. Yalan söylersen buradan bir yere gidemezsin..."'

Shan-po (şarkı söylüyor): 'Ben Shan-po, öğretmenimin eşinin sözlerini işittim. Kuzular gibi önünde diz çöküyorum. Herşeyi baştan sona kadar anlatacağım.'

- 'Biz ikimiz yolda birbirimize rastladık. Konuşarak, gülüş̧erek arkadaşlık ettik. Böylece kardeşlik yemini verdik.' 'Yüksek Dağ’a ögrenim yapmak için geldik. Gerçek budur. Hiç bir yalanım yoktur.'

Jui Lien (şarkı ile): 'Siz dersanede çalışınız. Ben yatak odama iplik bükmeğe gideceğim.' (Yatak odasına gidiyor ve iplik bükmeğe başlıyor. 
Bir taraftan da düşünüyor. Birden aklına Yin-t'aı geliyor. Onun gerçekten bir erkeğe benzemediğini hatırlıyor. $O$ erkek elbiseleri giymiş bir kız gibi idi. Ona yeniden bakmak için dersaneye gidiyor.)

- 'Bu akşam Chu Ying-t'ai'ya fazlaca şarap içireceğim. Ve onun erkek elbiseleri giymiş bir kız olup olmadığını anlıyacağım. Şimdi iplik bükmeyeceğim. Çalışma odasına gidip onu gözetleyeceğim.' (Yatak odasından çıkıp çalışma odasına giriyor. Ying-t'-aı'yın bir kenarda kitap okuduğunu görüyor. Shan-po ise kendi kendine bir şeyler mırıldanıyordu. Sonra Ying-t'ai'ya birşey söyledi. Biraz sonra, kolunun biri tarafından çekildiğini anlıyan Pai-jui Lien, başını çevirdi ve Shanpo'u gördü.)

Jui Lien : 'Neden kolumu çekiyorsun?'

Shan-po : 'Beraber gitmemizi istiyorum. Nereye gidelim?'

Jui Lien : 'Kardeşini çağır, birlikte gidelịm.'

Shan-po : 'Ben yalnız sizinle gelmek istiyorum.'

Jui Lien : 'Sen çalışmana bak. Sonra seni çağıracağım. Güzel yemekler vereceğim.'

Shan-po : 'Peki ben çalışmağa gidiyorum.'

Jui Lien (şarkı söylüyor): 'Görüyorum ki, Shan-po dersini çalışıyor.' (Kalbi heyecanla doluyor. Chu Ying-t'ai'yi alıp yatak odasına giriyorlar. Öğrencisine oturması için yer gösteriyor.)

Ying-t'ai (şarkı söylüyor): 'Öğretmenimi selâmlarım.'

Jui Lien (Şarkı ile): 'Öğrencim bir kenara oturup kitap okusun. Ben lambanın yanına iplik bükeceğim. İşimiz yok. Konuşasak iyi olur. Öğrencim nerede oturuyor?'

Ying-t'aı (şarkı ile): 'Şeftali bahçesinde değil de, zerdali bahçesinde oturuyoruz.'

Juin Lien (şarkı ile): 'Ailen nasıl, iyiler mi?'.

Ying-t'aı (şarkı ile): 'Ailem çok iyi. yim?)

Jui Lien : 'Öğrencimin kaç kardeşi olduğunu sorabilir mi-

Ying-t'ai (şarkı ile) Bu öğrenciniz olan erkek çocuk.'

Jui Lien (şarkı ile): 'Evinizde evlenecek genç var mı?'

Ying - t'a1 (şarkı söyleyerek):'Ben erkek olduğum için hiç kimsenin benimle evlenemiyeceğini söyleyebilirim.' 
Jui Lien (şarkı ile): 'Öğrencimden bu sözleri duydum. (Bunda bir iş var). Sen şarap içer misin? yok.'

Ying-t'aı (şarkı ile): 'Öğrenciniz bunu istiyor amma, cesareti

Jui Lien (şarkı ile): 'Eğer istiyorsanız, niçin içmeyeceksin?'

Ying-t'aı (şarkı ile): 'Öğretmenimin beni ayıplayacağından korkuyorum.'

Jui Lien (şarkı ile): 'Öğrencimin isteği varsa içsin. Senı kimseye söylemem. Bekle, şarap kadehlerini getireyim. (şarap kadehine içki doldurup öğrencisine içmesini söyler).

Ying-t'aı (şarkı ile): 'İlk önce öğretmenimin eşi içse. Sonra da ben içerim.'

Jui Lien : 'Öğretmeninin eşi doğduğu gündenberi içki kullanmamıştır. Öğrencisine sıgara içerek eşlik edecektir.'

Ying-t'aı (şarkı söyleyerek): Görüyorum ki, öğretmenimin eşi içki kullanmıyor. (Utana, utana ve yavaş, yavaş içki kadehini kaldırıp içiyor.)

Jui Lien (şarkı söylüyor): 'Öğrencimin içkiye karşı çok istekli olduğunu görüyorum. Bir damla şarapla sarhoş olmaz. (Hemen küçük kadehi alıyor ve yerine büyüğünü koyuyor.)

Ying-t'ai (şarkı söylüyor): 'Bir, iki, üç kadeh içtim. Yine sarhoş olmadım.'

Jui Lien : Öğrencim uyan, şarabını iç.'

Ying-t'ai : Sarhoş oldum galiba!'

Jui Lien (şarkı söylüyor): 'Görüyorum ki, öğrencim sarhoş oldu.' (Kalbi sevinçle doluyor. Gidip kapının iki kanadını kapatıyor. Kocası gitmek için hazırlanıyordu. (şarkı ile): 'Onun başındaki başlığı çıkarıyorum. Saçları meydana çıkıyor. Açık mavi buluzunu da çıkarıyorum. Çiçekli bir kadın çamaşırı görünüyor. Güzel siyah çizmelerini de çıkarıyorum. Küçücük ayakları meydana çıkıyor!.

Jui Lien : 'Öğrencim uyan. Öğretmenin 'Dağ'dan geldi.'

Ying-t'ai (şarkı söylüyor): 'Şarap beni sarhoş etti. Kulağımın dibinde birtakım sesler duyuyorum. Fakat neden gözlerimi açınca böyle 
şaşkın bakıyorum. Çizmelerimi, başlı̆̆ımı ve elbiselerimi görüyorum. Söylemem gerekmiyor. Öğretmenimin eşi gerçeği anladı.' (Ö̉ne eğilerek selam veriyor).

Jui Lien : 'Neden böyle selâm veriyorsun?'

Ying-t'ai (şarkı ile): 'Bir genç kız gibi sizi selâmlıyorum. İki dizimi büküyor, bana yardım etmenizi için size yalvarıyorum. Öğrencinizin 'Dağ'dan gitmesine yardım ediniz.'

Jui Lien (şarkı ile): 'Size çok kızgınım. Ailenizin bir erkek çocuğa yoksa 'Tanrıya' yalvarsınlar. 17-18 yaşındaki genç bir kızın 'Yüksek Dağ’a gönderilmesi doğru bir şey değil. Ben dikkat etmeseydim. arkadaşların bunu öğrendikleri zaman bir kargaşalık çıkarabilirlerdi. Onların kötü sözleri seni üzerdi. Onların bağırmaları da beni sinirlendirirdi. Başındaki güzel başlık saçlarını saklıyor. Mavi buluz çiçekli çamaşırlarını gizliyor. Çizmelere ve çükük ayaklarına bakıyorum da, çizmeler ayakların küçük olduğu için büyük geliyor. Öğrencime bunları nasıl giyebildiğini sorabilir miyim?'

Ying-t'a1 (şarkı ile): 'Ayaklarım küçük olduğu için çizmeler ayağıma büyük geliyor. Bunun için içine pamuk doldurdum.

Jui Lien (şark1 söylüyor): 'Öğrencimin ayağının çok küçük olduğunu görüyorum. Bu gibi işlere kalkışmak büyük cesaret. Öğrencime benimle beraber gelmesini ve ağabeyisiyle konuşacağımı söylemesini istiyorum. '(Hemen yatak odasından çıkıp çalışma odasına giriyorlar.)

Jui Lien : 'Ağabeğin seninle beraber gelecek. Yarın sabah 'Dağ'dan gideceksiniz.

\section{Ying-t'ai : Felâket!'}

Jui Lien (şark1 söylüyor): 'Göğe doğru yükselen bir ağlama sesi duyuyorum. karşılaşacağı felaketlerin ne olduğunu anladığını zannediyorum.'

Jui Lien : Bir plan hazırladı. 'Altın Tuğla'dan bir parça aldı. Ying-t'ai ve Shan'-po'ya birçok mürekkep taşı getirmelerini söyledi.

Jui Lien : 'Size bir paravana verecğim. Sonra, her gün bir elle yazı yazıyordunuz. Bu gün iki elle yazı yazacaksınız. Shan-po siyah kalemle, Ying-t'ai ise kırmızı kalemle soy adını ve kendi adını yazacak. Ayaklarınızı altınıza alıp uyumanıza izin veriyorum. Uzanıp uyumanızı asla istemiyorum. Shan-po yere devrilince Ying-t'ai ona vuracak. Ying-t'ai yere yatınca yine Shan-po'ya vuracak.' 
Shan-po (şarkı söylüyor): 'Neden hep bana vurulacak?'

Jui Lien (şarkı ile): 'Sen olan şeyleri anlıyamazsın. İçeride bir kadın elbisesi ve saç iğneleri var. Ben 'Altın tuğla'yı ikinizin yatağı arasına koyacağım. Öğrencilerim arkamdan gelsinler.'

Shan-po (şarkı söylüyor): 'Gözcü kulesindeki davul sesini duyuyorum. Korkuyorum ve çok kızıyorum. Doğru birşey yapmadığı için aileme kızıyorum. Niçin beni 'Yüksek Dağ'a gönderdiler. Beni buraya gönderirken de yorgan vermediler.! (Shan-po, üşüyorum diye bağırır.)

Ying-t'ai (şarkı söylüyor): 'Ủzerimdeki mavi buluzu çıkarıp ağabeğimin üstüne örtüyorum. Gözcü kulesindeki davulun birkaç defa vurduğunu duydum. Şimdi'3' davulunun sesini duyuyorum. Korkuyorum. Yatağının yanında duruyor ağabeyime sesleniyorum.' yorum.'

Shan-po (șarkı söylüyor): 'Paravananın devrileceğinden korku-

Ying-t'ai (şarkı söylüyor): 'Eğer altın tuğlayı devirirsen, yarın sabah kaldırırız.'

Shan -po (şarkı ile): 'yapamam ' diye elleriyle birtakım hareketler yapıyor.

Ying-t'ai (şarkı söylüyor): 'Çok aptal ve budalasın. Chu Ying-t'aişimdi sevgi işlerini hiç düşünmüyor. $O$ anda '4' nöbeti' sesini duyuyor. Rafın üstündeki altın horoz kanatlarını çırparak bağırıyor. Horoz kanatlarını çırparken 'Ying-t'ai artık elbiselerini giysin' diye bağırıyor.

Ying-t'ai : 'Hemen elbiselerimi giyiyorum.'

Shan-po (şarkı söylüyor): 'Şimdi' ' 5 nöbetini' duyuyorum. Korkuyorum. Kapının iki kanadını açıyorum. Kuzey-doğudan güneş doğuyor. Kardeşimi birkaç defa çağırıyorum. durmadan çağırıyorum. Tanrı bilir ki, altın tuğlayı düşürmedik. Artık 'Dağ'dan ayrılacağız.'

Ying-t'aı : 'Kardeşim başka yerde öğrenimini yapacak.'

' Shan-po : Başka okullarda kutsal kitaplar okudum. ve 'Yüksek Dağ'da ise ayaklarımı altına alıp uyudum.'

Ying-t'ai : 'Büyük ağabeyim, kardeşine' Dağ'dan hemen inmesine yardım edecek.'. ${ }^{36}$

36-Bizim elimizdeki metin burada bitiyor. Halbuki diğer kaynaklarda sonuç başka başkadır. Genel olarak, birbirine kavuşamayan gençler ölürler, ancak öteki dnyada birleşirler. Ve onlar halkın nazarında artık 'ölümsüz insanlar'dır (bak. diğer kaynaklar: alt not $32-33-34-35$ ). 

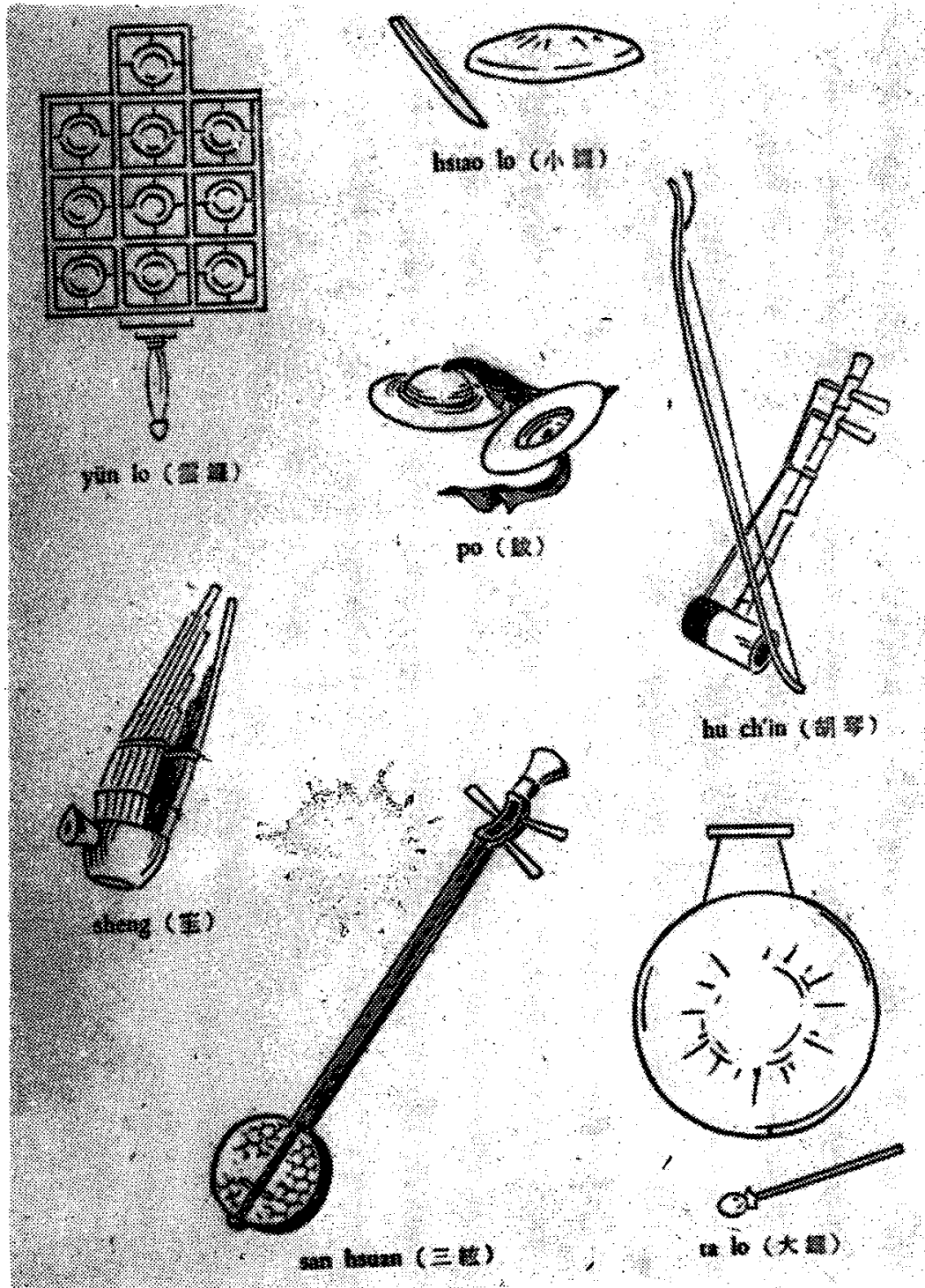

Resim 1-Müzik aletleri 


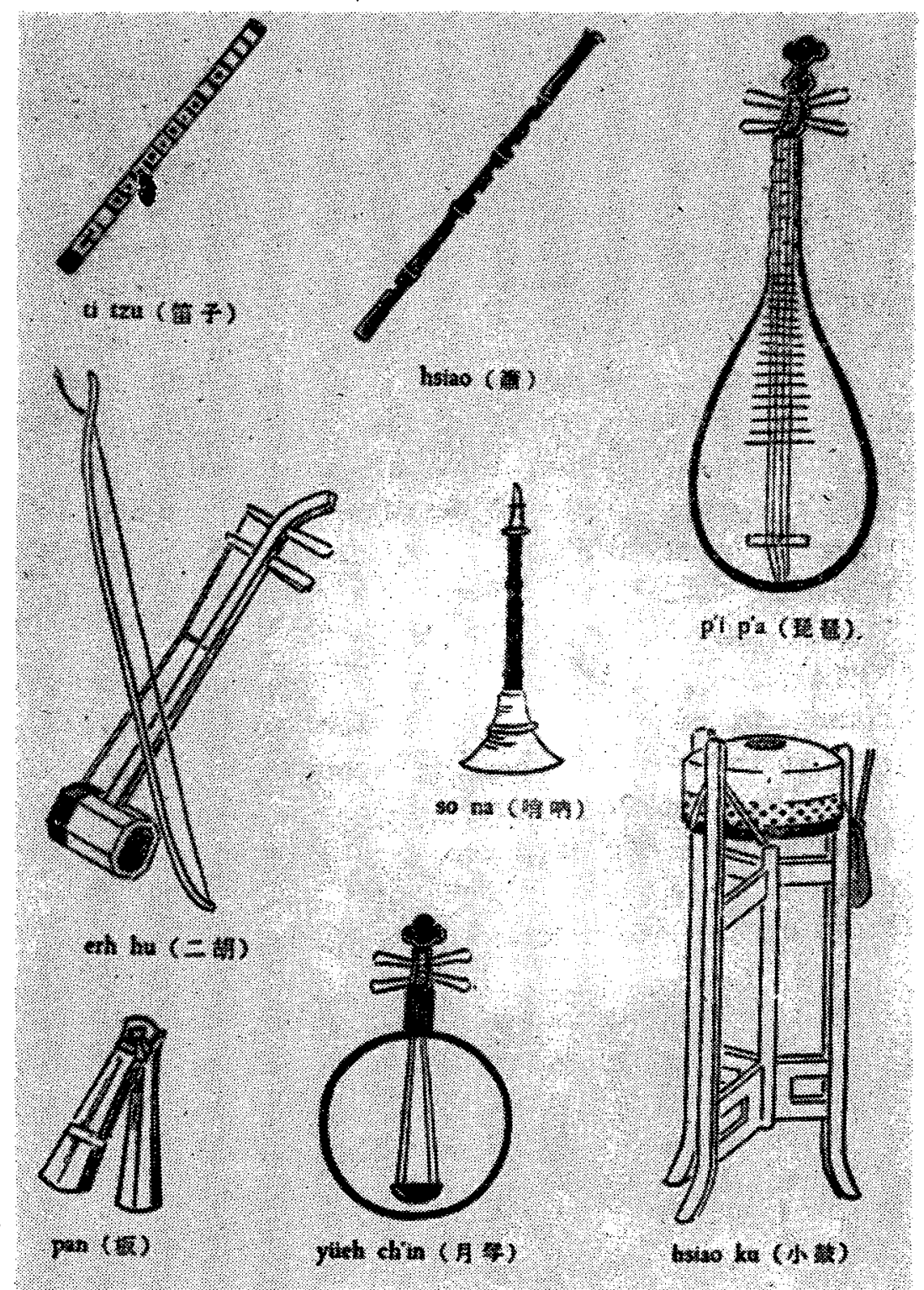

Resim 2-Müzik aletleri 


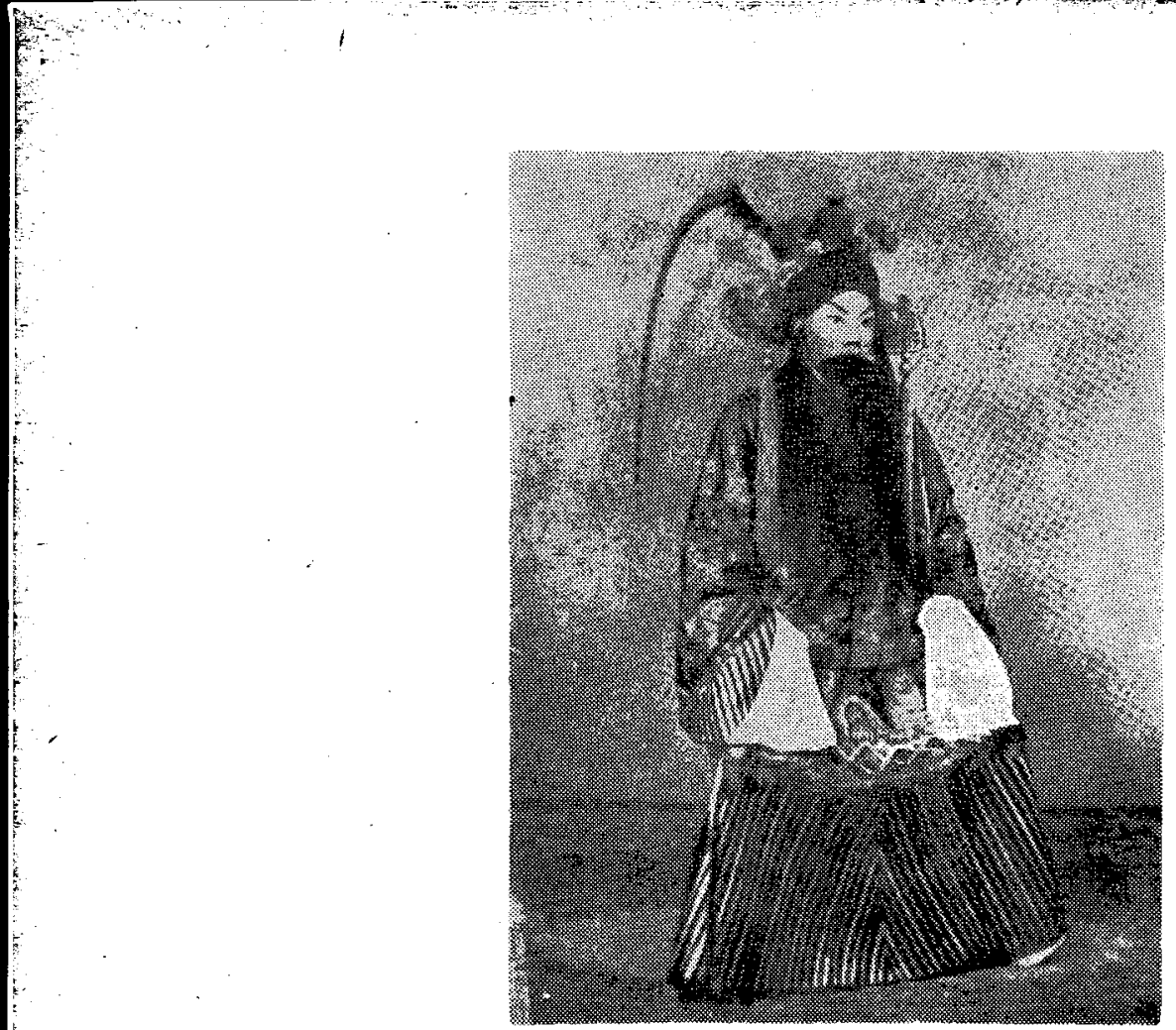

Resim 3-Bir Sheng sanatçısı

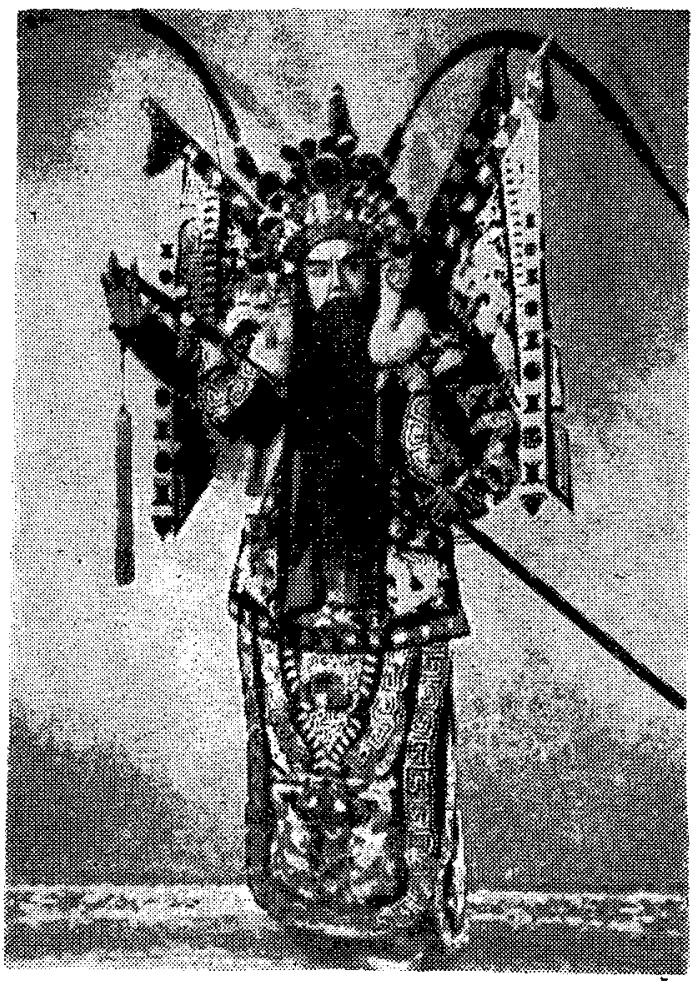

Resim 4-Bir general 


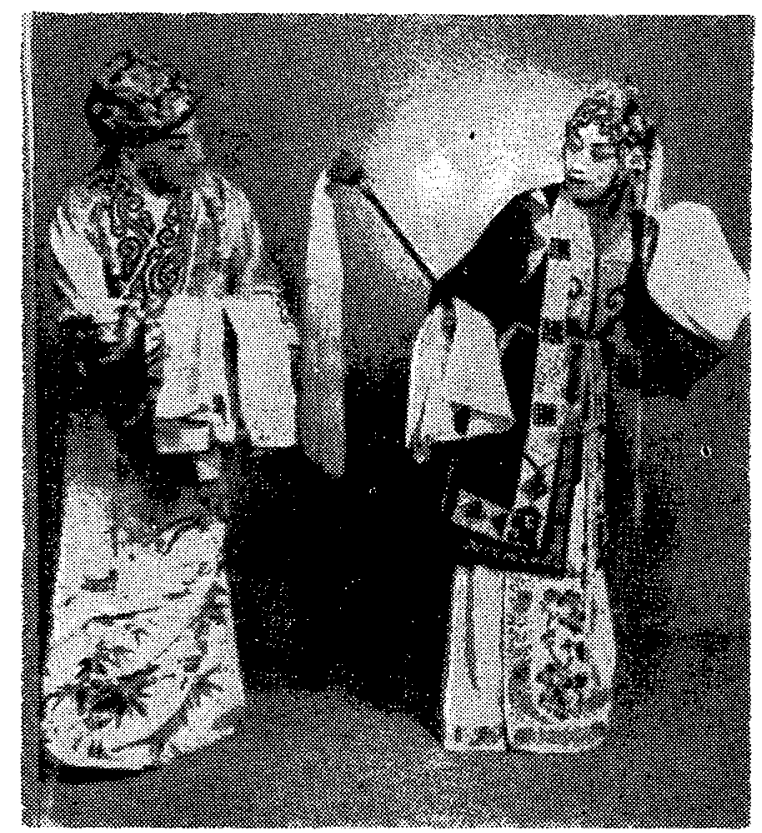

Resim 5-Hsiao Sheng.

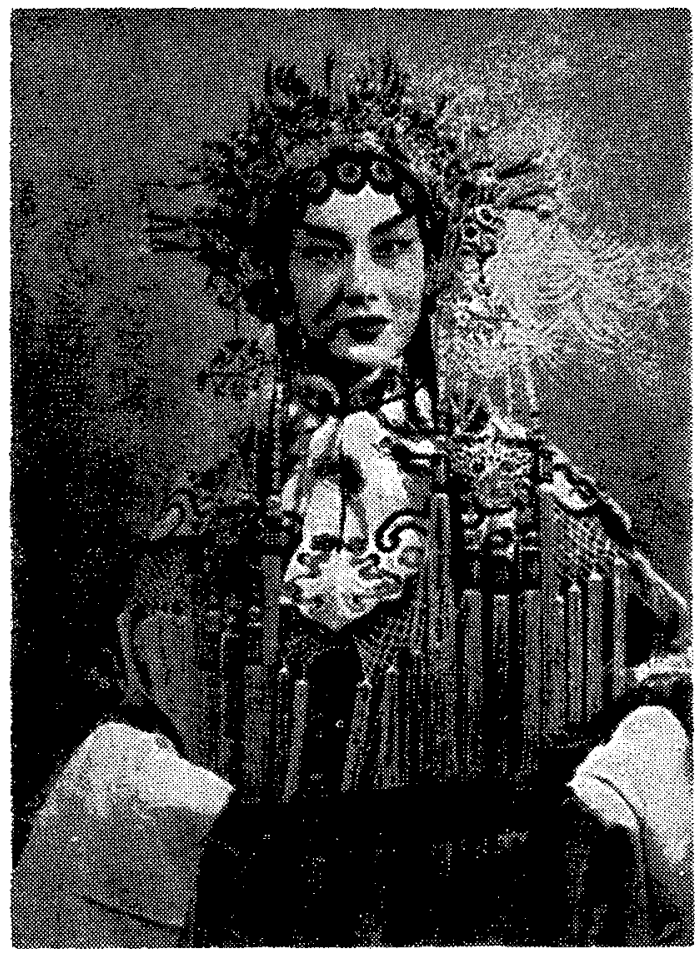

Resim 6-Bir Tan sanatçısı 


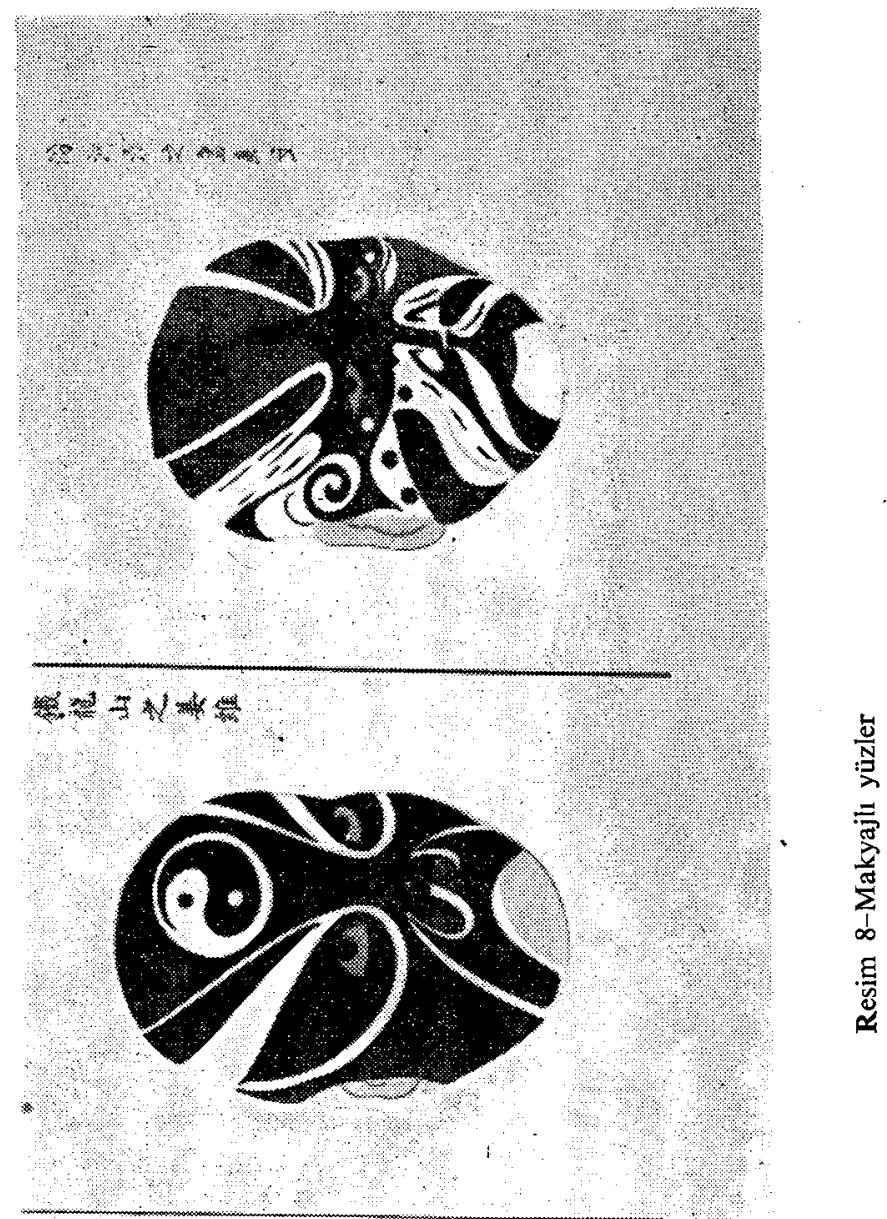

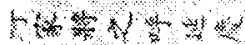

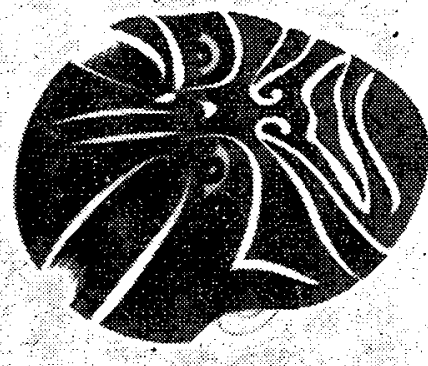




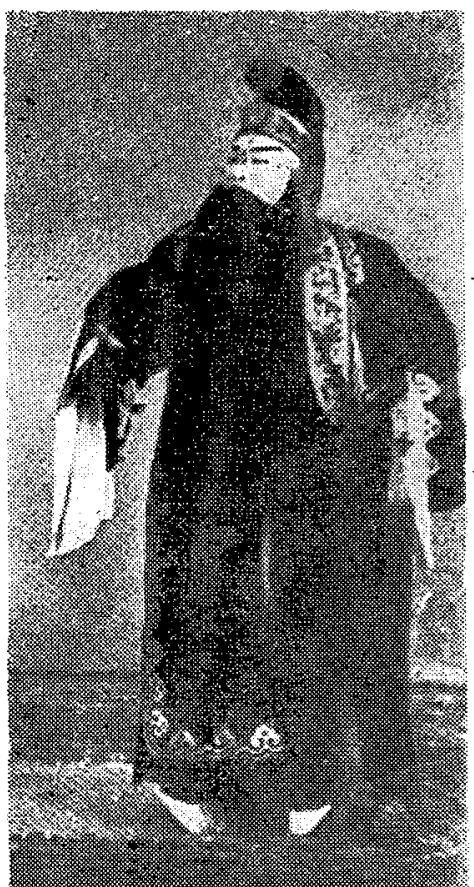

Resim 7-Bir Ching sanaţ̧ıs

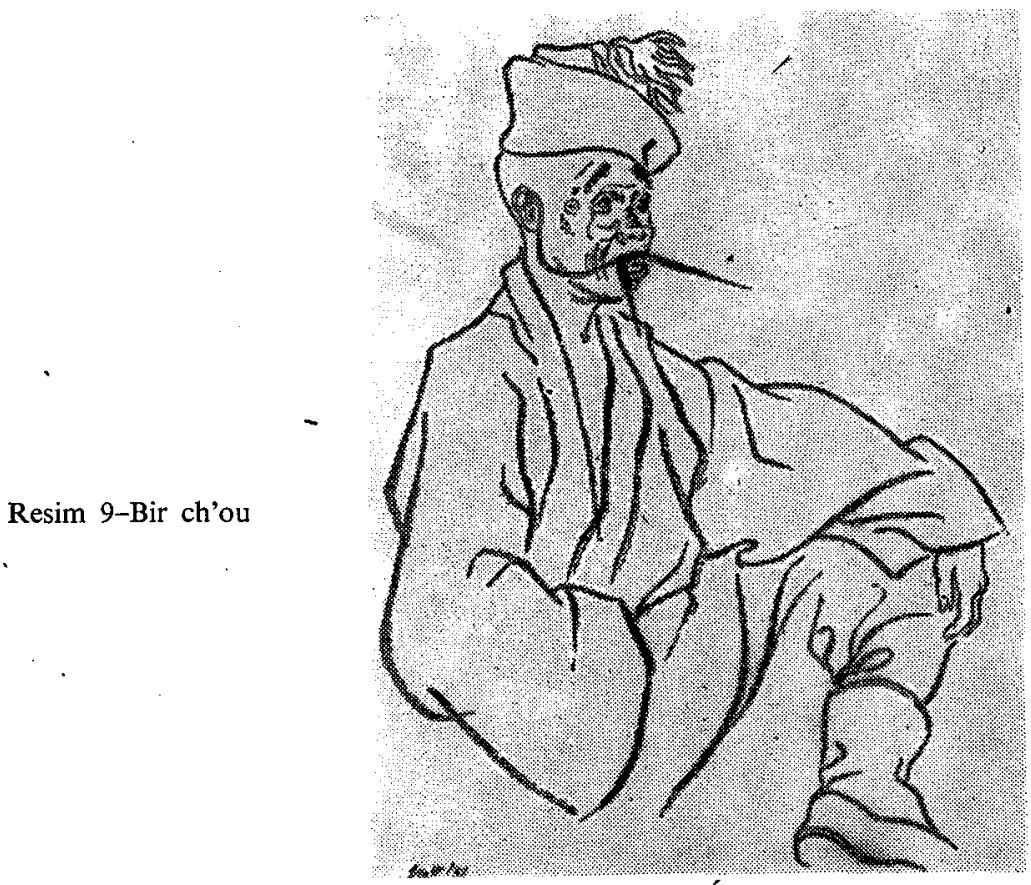




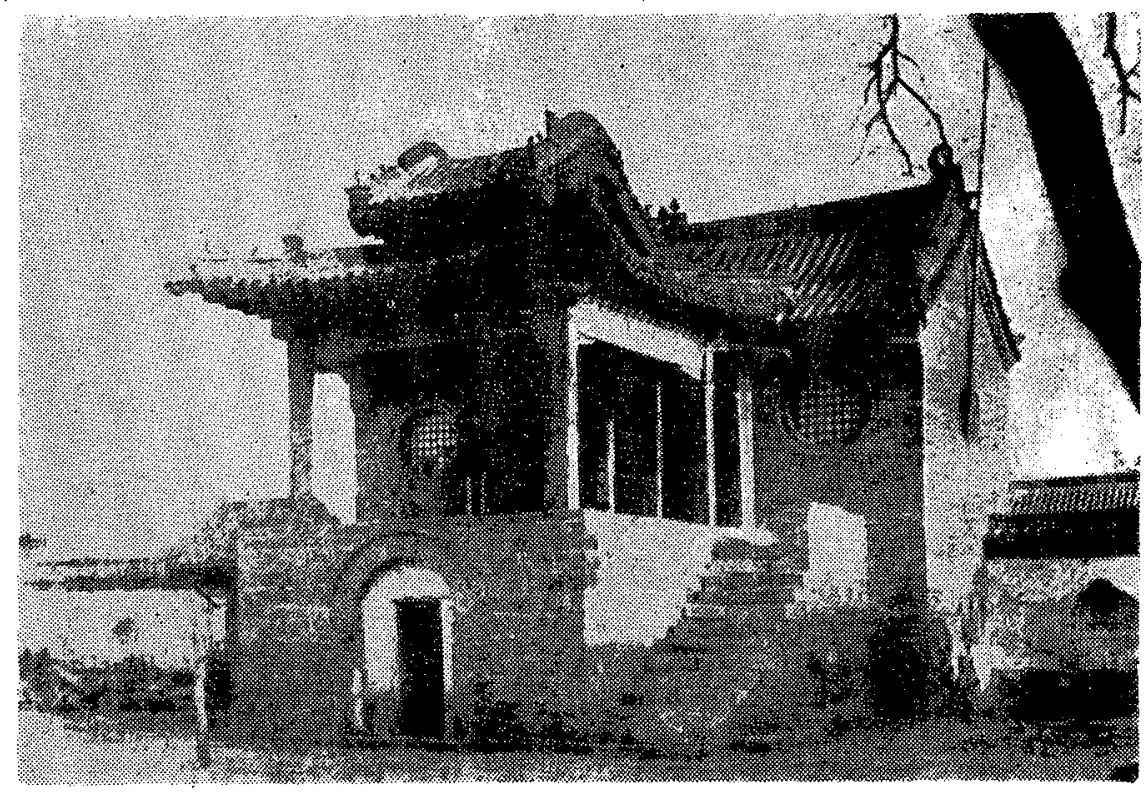

Resim 10-Tiyatro binası

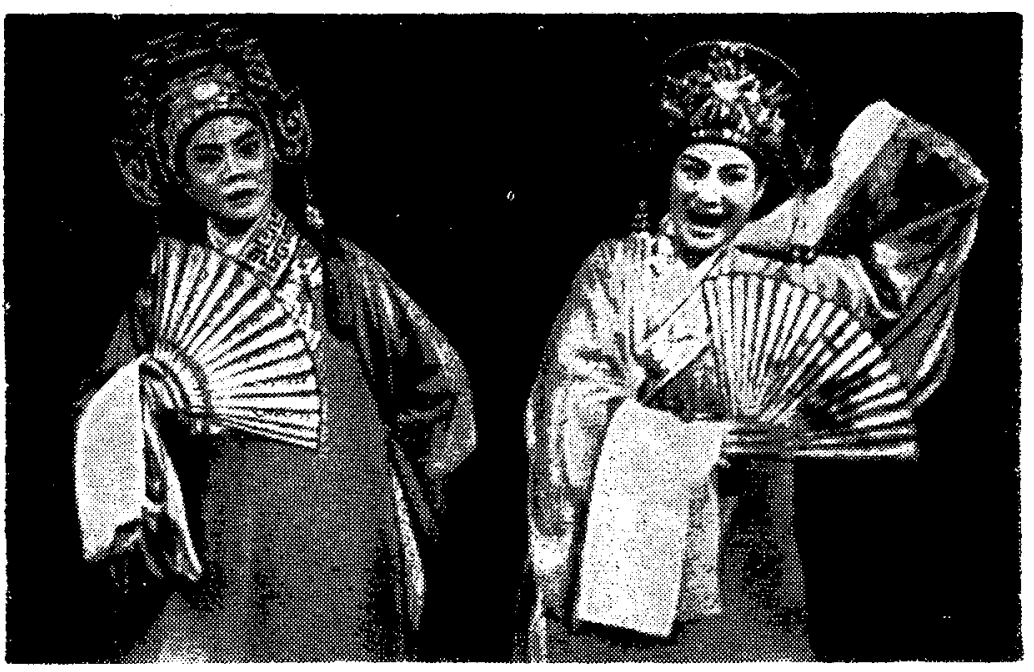

Resim 11-Liang Shan - Po ve Chu - Ying - l'ai 